\title{
Mechanism of Aqueous Humor Secretion, Its Regulation and Relevance to Glaucoma
}

\author{
Mohammad Shahidullah ${ }^{1}$, \\ Waleed Hassan Al-Malki ${ }^{2}$ and Nicholas A. Delamere ${ }^{1}$ \\ 1Department of Physiology, University of Arizona, Tucson, AZ 85724 \\ ${ }^{2}$ College of Pharmacy, Department of Pharmacology and Toxicology, \\ Umm Al-Qura University, Makkah, \\ 1USA \\ ${ }^{2} \mathrm{KSA}$
}

\section{Introduction}

The principal function of the eye is to receive the light signal from the environment and transmit it to the brain to create vision. This requires that the structures of the eye involved in light transmission, such as the cornea and the lens, must be transparent. Unlike other tissues of the body, nutrients and oxygen supply to these structures must be accomplished without blood interference in transmission of light, i.e., these structures must be avascular. Apart from this, the eye must also maintain optimum pressure within the globe, which is important to give the rigidity necessary for optical alignment of the cornea, lens and the retina. The eye achieves this by the production, accumulation and circulation of a clear fluid called aqueous humor $(\mathrm{AH})$. $\mathrm{AH}$ is produced by selective transfer of solutes and water from the blood plasma by a complex ocular epithelium, the ciliary epithelium. The fluid then accumulates in the two special compartments within the eye, and the excess leaves the globe to enter the blood through complex pressure dependent outflow pathways. This complex arrangement of production, accumulation and drainage of aqueous humor contributes to the nutrition and survival of the avascular tissues as well as to good optical properties of the eye. However, this also poses a problem in that any imbalance in the production and drainage of aqueous humor inevitably causes abnormal intraocular pressure (IOP). For example, in case of insufficient drainage, excess accumulation of fluid within the globe will raise the IOP to higher than the physiological level; a clinical condition called glaucoma. Abnormally high pressure causes death or degeneration of the light sensitive and signal transmitting tissues of the eye leading progressively to partial or complete blindness. Understanding the mechanism of $\mathrm{AH}$ secretion and its regulation is important to develop rational and target specific drugs for the treatment of glaucoma. In this chapter we will try to present the readers with a comprehensive and up to date description of the relevant ocular anatomy, physiology, biochemistry and pharmacology of $\mathrm{AH}$ secretion and its relevance to pathophysiology of ocular hypertension or glaucoma. 


\section{Gross structures of the eye}

The two eyes together with the appendages (extraocular muscles, lacrimal glands) are situated within the conical or four-sided pyramidal cavities of the skull called the orbits. The eyeball is a sphere, with the segment of a smaller sphere, the cornea, in front. It is composed of three layers or tunics. The outermost protective layer is made up of the sclera posteriorly and the cornea anteriorly. The middle layer is mainly vascular, consisting of the choroid, ciliary body and iris. The innermost coat is the retina, containing the essential sensory elements responsible for vision - the rods and cones, bipolar and ganglion cells. Within the three layers are the refractory media - namely, the $\mathrm{AH}$, the crystalline lens and a clear jelly, the vitreous humor (Fig. 1).

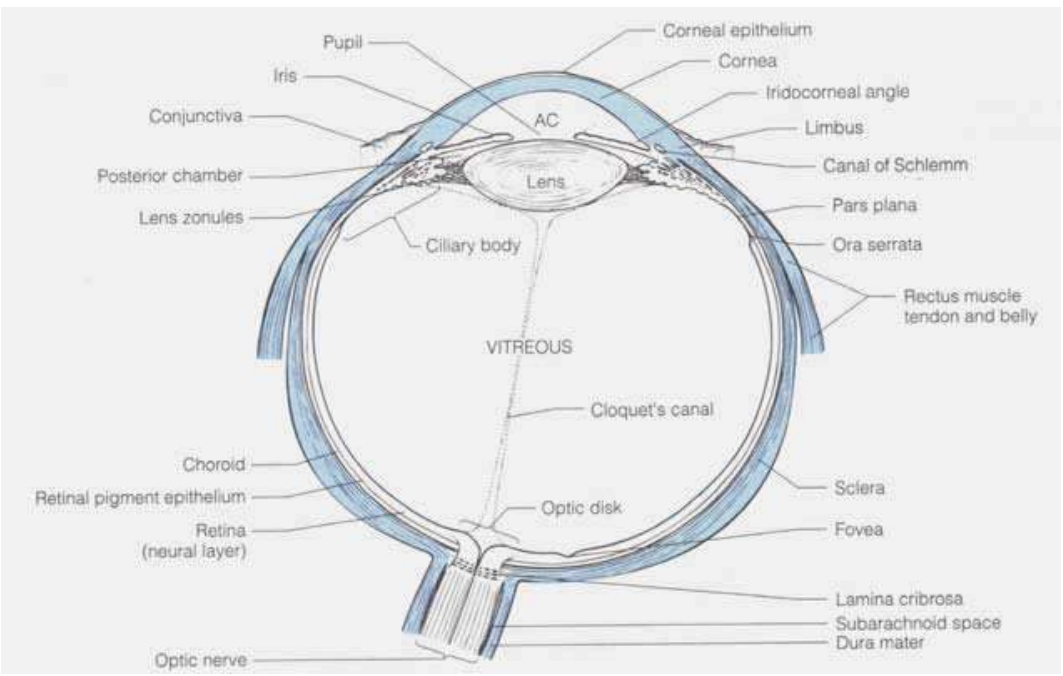

Fig. 1. Diagram of the human eye in horizontal section showing major structures and the arrangement of the three layers (Forrester et al., 1996) (used with permission)

The cornea, the first and the most powerful refracting surface of the optical system of the eye, occupies the anterior sixth of the outermost coat. The crystalline lens is a double convex, transparent body positioned between the iris and $\mathrm{AH}$ in front and the vitreous humor behind, and is supported by an elastic capsule and the ciliary zonules (the suspensory ligaments). The ciliary zonules attach the lens to the ciliary body. The iris, a pigmented structure, is the most anterior portion of the vascular tunic of the eye. It is composed of a flat bar of circular muscle fibers surrounding the pupil and a thin layer of smooth muscle fibers by which the pupil is dilated. Relaxation and contraction of the iris regulates the size of the pupil and hence the amount of light entering the eye. It is covered by two layers of epithelia, which are continuous extensions of the pigmented and nonpigmented layers of the ciliary body (CB) epithelium. The CB is the middle thickened portion of the vascular tunic anterior to the ora serrata (the terminating point of the retina at the $\mathrm{CB}$ ), connecting the choroid with the iris. It is composed of corona ciliaris (the ciliary processes and folds), ciliary ring, ciliary muscle and a basal lamina. The ciliary processes are finger like projections that extend into the posterior chamber, approximately 70 in number 
in man and 90 to 110 in bovine (Prince et al., 1960). These are composed of capillaries, which are covered by a double layer of epithelium, called the ciliary epithelium (CE). The CE is the key structure responsible for $\mathrm{AH}$ production. The choroid is the thin portion of the vascular coat extending from the ora serrata to the optic nerve. It supplies blood to the retina and conducts arteries and nerves to the anterior structures of the eye. The retina is the innermost layer of the three tunics of the eyeball surrounding the vitreous body and continuous posteriorly with the optic nerve. Grossly, the retina is composed of an outer single layer of pigmented epithelial cells (pars pigmentosa), and an inner transparent layer (pars nervosa), which is part of the optical component. The neural retina has many cell types, arranged in distinct layers, including the essential neurons to receive and carry light signal to the brain. The rod and cone (photoreceptor) layer of the neural retina forms the percipient element of the retina (i.e., the element that responds to visual stimuli by a photochemical reaction) and is connected via the bipolar cells to the nerve fiber layer, the ganglion cell layer. The axons of the ganglion cells bundle together to form the optic nerve. The optic nerve in turn extends and carries the light-induced impulse to the brain.

The $\mathrm{AH}$ and vitreous body are contained in the three spaces within the eyeball. The largest space is situated between the lens and retina and contains the vitreous humor. The smaller two spaces are called the aqueous chambers (anterior and posterior). The anterior chamber contains most of the aqueous and is the space between the anterior surface of the iris and the internal surface of the cornea. The posterior chamber is the name given to the smaller space surrounded by the lens, the iris and the CB.

The vitreous is a clear hydrophilic mass and physiologically a hydrogel that occupies more than two thirds of the intraocular volume. Forward extensions of the hyaloid membrane form the suspensory ligaments supporting the lens, known as the zonules. The vitreous is probably not a tissue in proper sense, but rather a highly specialized extracellular fluid containing connective tissue-specific elements, such as collagen fibers, hyaluronic acid (hyaluronan) and some other soluble proteins and glycoproteins. Its density, refractive index and pH is slightly higher than those of pure water (Gloor, 1987; Redslob, 1932) and its water content is extremely high, between 98\% (Leone et al., 2010; Redslob, 1932) and 99.7\% (Sullmann, 1951). The mechanical stability and optical transparency of the vitreous comes from the specific organization of the collagen-hyaluronan network. The vitreous allows light to reach the retina and nutrients to diffuse from the $\mathrm{CB}$ to the retina.

\subsection{Ocular blood supply}

The blood vessels of the choroid supply many of the internal structures of the eye. The choroid, CB and iris are supplied by the ciliary system of arteries, comprising the medial and lateral long posterior ciliary arteries, the short ciliary and the anterior ciliary arteries. These are often referred to as the uveal vessels. They emanate from the main arterial supply to the eye, the ophthalmic artery, which is derived from a branch of the internal carotid artery in the human. The venous blood from the uvea drains into the episcleral veins. These are fine veins running through the sclera and from there into the four vortex veins, finally leaving the eye by the superior and inferior ophthalmic veins. The neural retina is supplied from the central retinal artery, a branch of the ophthalmic artery arising proximal to the ciliary arteries. The venous blood from the retina drains into the retinal veins and then into the ophthalmic veins. Fig. 2 shows the physiological plan of ocular blood supply in human. 


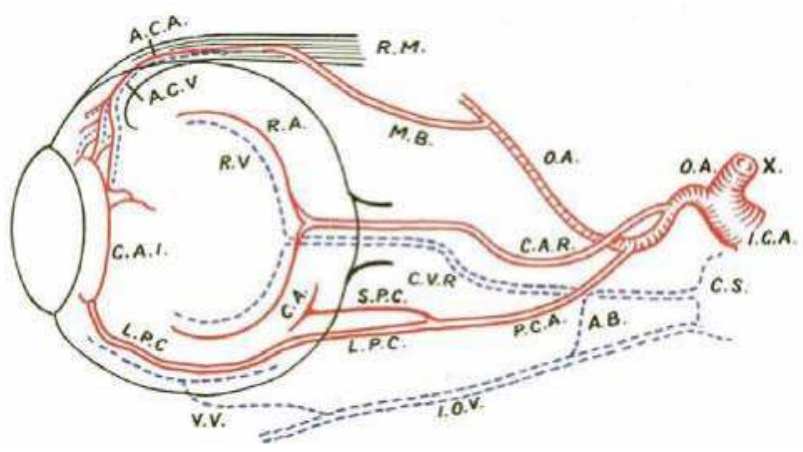

Fig. 2. Diagram showing physiological plan of the circulation in human eye (Duke-Elder, 1926). CA, carotid artery; OA, ophthalmic artery; MB, muscular branch; CAR, central artery of the retina; PCA, posterior ciliary artery; ACA, anterior ciliary artery; LPC, long posterior ciliary artery; SPC, short posterior ciliary artery; ACA, anterior ciliary artery; ACV, anterior ciliary vein; $\mathrm{VV}$, vortex vein, IOV, inferior orbital vein (used with permission)

\section{Aqueous humor}

$\mathrm{AH}$ is a transparent fluid contained in the anterior and posterior chambers of the eye and is formed by the ciliary epithelium (CE) of the ciliary processes projecting from the CB. AH is formed by selective transfer of solutes (ions, glucose, ascorbate, amino acids and other solutes) and water from the blood across the CE. The fluid is continuously secreted by the $\mathrm{CE}$ and enters first into the posterior chamber. It then seeps forward through the narrow space between the lens and the iris and enters the anterior chamber through the pupil. From the anterior chamber it leaves the eye, mostly by bulk flow (a pressure dependent flow), through the two outflow pathways at the anterior chamber angle, i.e., the angle formed by the cornea and the root of the iris.

\subsection{Functions of aqueous humor}

$\mathrm{AH}$ is a nutritive fluid that serves as a blood substitute for the avascular cornea, lens, anterior vitreous and also the trabecular meshwork (TM) of the outflow pathway. AH supplies nutrients and oxygen to these avascular tissues through diffusion. It also removes metabolic wastes of the avascular tissues through its continuous formation, sojourn through the ocular chambers and drainage from the eye to the venous blood. Hydrostatic pressure due to $\mathrm{AH}$ establishes the IOP, which inflates the eye to maintain proper alignment of the optical structures. AH also serves to transport ascorbate, an anti-oxidant agent in the anterior segment. Presence of immunoglobulins in the $\mathrm{AH}$ indicates a role in immune response to defend against invading pathogens.

\subsection{Anatomical and structural features of the aqueous secreting tissue}

The ciliary body is the tissue responsible for AH secretion. The CB is a musculoepithelial structure, composed of the ciliary muscles and the ciliary processes. The ciliary muscles are responsible for accommodation and the ciliary processes are responsible for $\mathrm{AH}$ production. The bulk of the CB consists of three sets of ciliary muscles, the longitudinal, radial, and circular muscles. It is attached to the lens by connective tissue called the zonules of Zinn or 
simply ciliary zonules. The ciliary muscles, by relaxation or contraction, increase or decrease the thickness of the crystalline lens to focus light on the retina to produce near or distance vision. This process of shaping the lens is called accommodation.

The inner surface of the $\mathrm{CB}$, i.e., the surface facing the posterior chamber, is covered with a double layer epithelium. $\mathrm{AH}$ is formed by this epithelium. There are two distinct regions: the anterior third consists of undulated surface and is termed the pars plicata, while the smooth posterior two thirds is termed the pars plana. Projecting inwards from the pars plicata region into the posterior chamber are approximately 70 radial ridges called the ciliary processes (Fig. 3). Each process is $1 \mathrm{~mm}$ high, $2 \mathrm{~mm}$ long antero-posteriorly and $0.5 \mathrm{~mm}$ wide. In the bovine eye these processes are particularly well developed. The ciliary processes have a rich blood supply and are probably the most heavily vascularized part of the eye. The connective stroma in the interior of each process contains a mass of capillaries, arranged that each comes into close relationship, at some point in its course, with the $\mathrm{CE}$ covering the ciliary processes. A histological section of a porcine ciliary process are shown (Fig. 4).

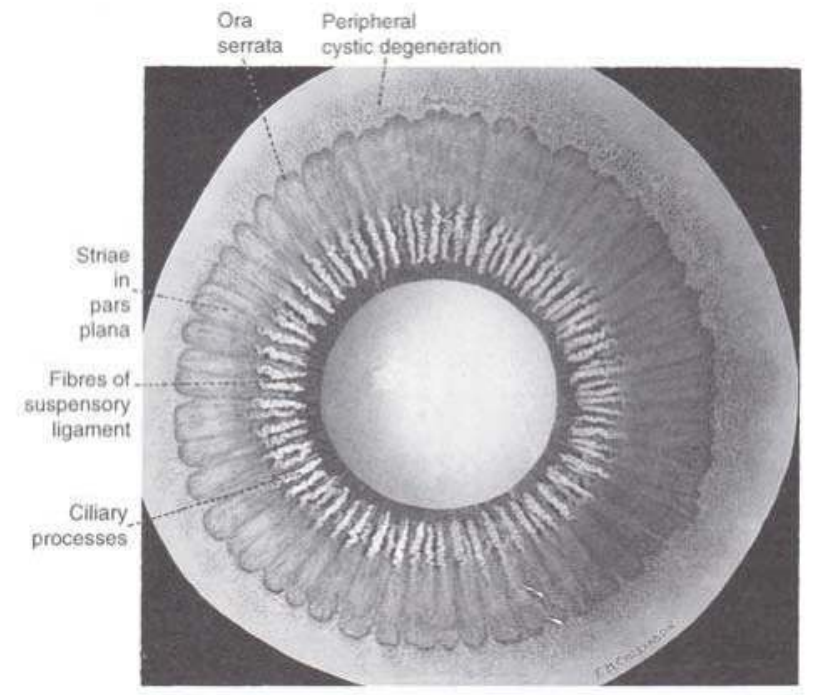

Fig. 3. Posterior view of the ciliary body showing ciliary processes and part plana (Bron et al., 1997) (used with kind permission from Springer Science+Business Media B.V)

The CE consists of an inner layer of nonpigmented epithelium (NPE) and an outer layer of pigmented epithelium (PE). The endothelium of the ciliary capillaries is highly fenestrated so a blood ultrafiltrate fills the stroma. This contains almost all components of the plasma except the blood cells. It is now generally believed that $\mathrm{AH}$ is formed mostly by active transport of ions and solutes across the CE. Selective transport of solutes takes place from the stromal fluid across the bilayer into the posterior chamber and this causes a subsequent osmotic flux of water, producing the $\mathrm{AH}$. The exact contribution of each cell type to the secretion of $\mathrm{AH}$ is not known. Most recent studies, however, suggest that both cell types function together as a syncytium to produce AH (Civan, 1998; Edelman et al., 1994; Raviola and Raviola, 1978). The contemporary view is that ions and other solutes driven inward from the blood side by the PE cells readily pass through the gap junctions into the NPE cells. 
From the NPE, ions and solutes are then secreted across the basolateral membrane into the posterior chamber (Avila et al., 2002; Civan and Macknight, 2004; Do and To, 2000; Jacob and Civan, 1996; To et al., 2002). The situation is complex, however, because NPE cells also may reabsorb some of the solute and water from the aqueous humor back into the stroma (Hu et al., 2011; McLaughlin et al., 2007). The algebraic sum of these secretion and reabsorption processes determines the net secretion rate of $\mathrm{AH}$ into the posterior chamber.

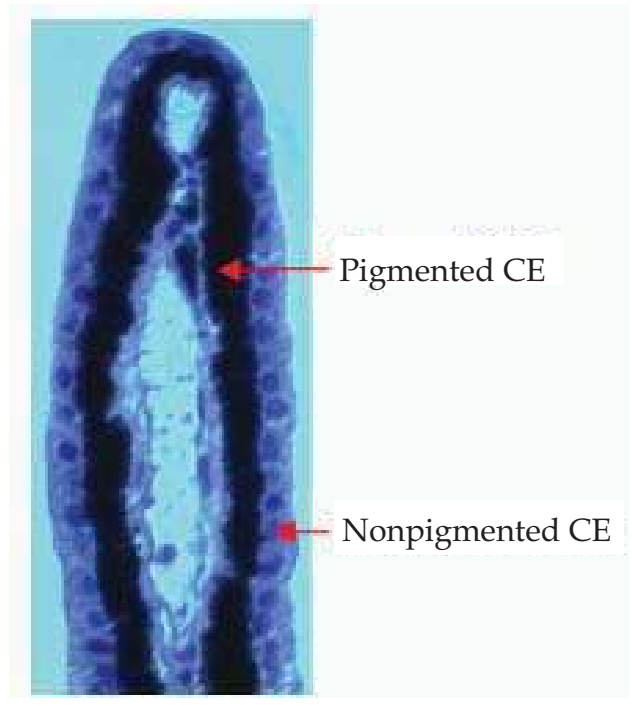

Fig. 4. A histological section of a porcine ciliary process (Shahidullah, 2010, unpublished data) showing pigmented and nonpigmented ciliary epithelial cells.

\subsubsection{Special features of the CE}

The bilayer CE consists of the columnar non-pigmented (NPE) and the cuboidal pigmented epithelial cells (PE). The basal surface of the NPE cells lines the posterior chamber whereas the basal surface of the PE cells rests on the ciliary body stroma (Fig. 5). The apices of the PE and NPE cells are in contact with each other and are connected via gap junctions. This unusual arrangement is the result of the invagination of the neuroepithelial layer during embryogenesis. Despite this arrangement, the secretory process is directed from apex to the base of the NPE cells along the lateral intercellular canals, which are 'closed' at the apical ends by dense junctional complexes, the tight junctions (Cole, 1977; Raviola and Raviola, 1978). The PE represents the forward continuation of the retinal pigment epithelium whilst the NPE layer is the forward continuation of the neuroepithelium from which the retinal cells are derived. Under electron microscopy, the cells of this epithelium display characteristics typical of secretory epithelia, i.e. interdigitations on the lateral surfaces of adjacent cells and basal infoldings (Pappas and Smelter, 1958; Pappas and Smelter, 1961). The coordinated function of the two epithelial cell layers is of importance, since the secreted aqueous must be derived from the blood contained in the capillaries of the ciliary stroma and secretion must occur across both layers. Fig. 6 shows an electron microscopy image of PE and NPE. 


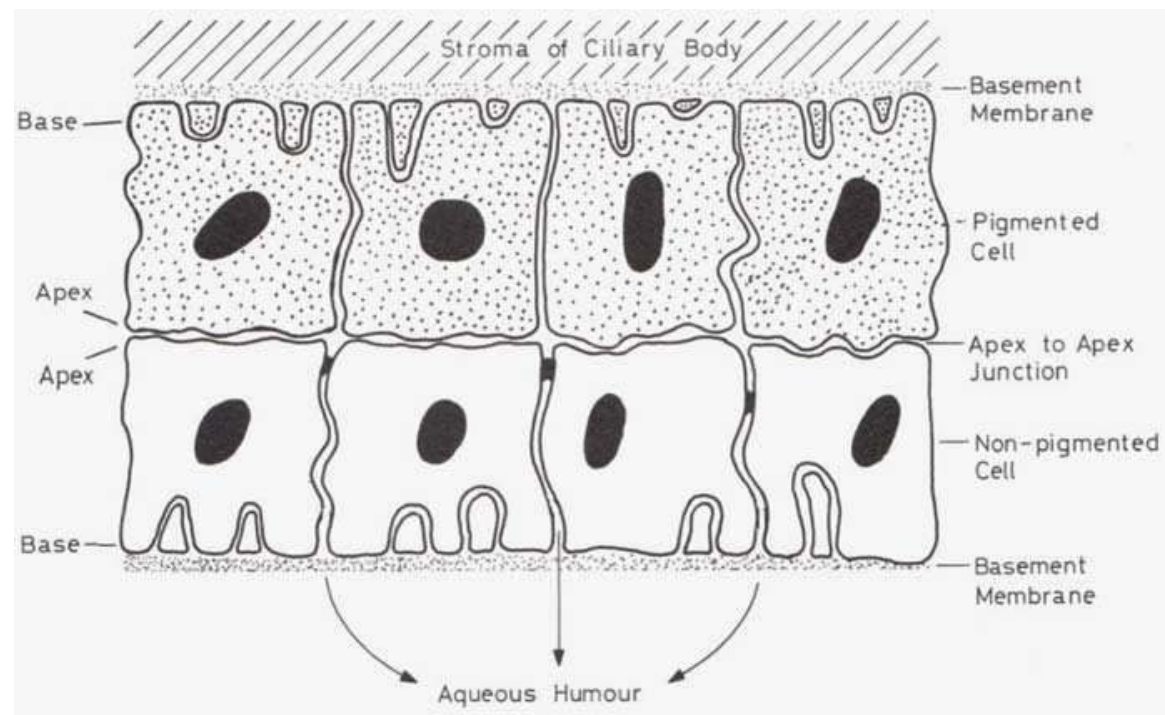

Fig. 5. Schematic diagram of ciliary epithelium bilayer showing apex to apex arrangement of pigmented and non-pigmented ciliary epithelium (Davson, 1990) (used with permission)

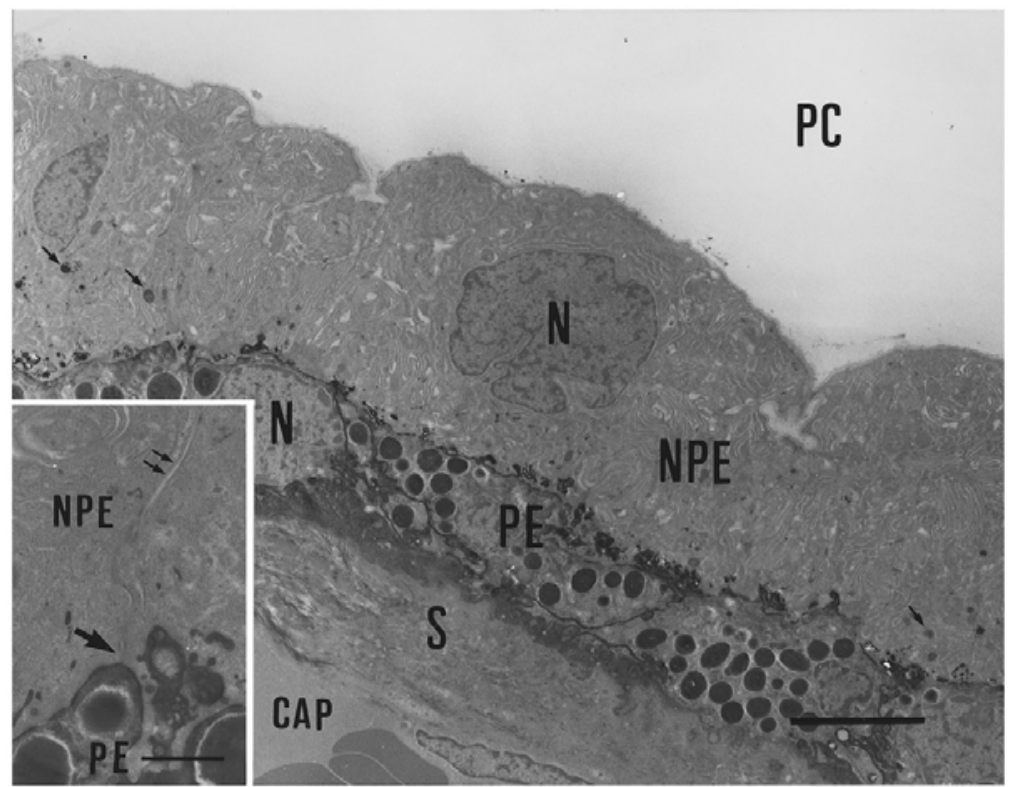

Fig. 6. Transmission electron microscopy image of CE showing PE and NPE cells. CE, ciliary epithelium; PE, pigmented ciliary epithelium; NPE, nonpigmented ciliary epithelium; PC, posterior chamber; $\mathrm{N}$, nucleus; $\mathrm{S}$, stroma; $\mathrm{CAP}$, capillary. Bar $=5 \mu \mathrm{m}$ (inset bar $=1 \mu \mathrm{m}$ ) (Chen et al., 1996) (used with permission) 
The $\mathrm{CB}$ epithelium represents a significant barrier to the movement of substances from the blood into the eye (Cunha-Vaz, 1979; Freddo, 2001). The vasculature perfusing the CB is highly fenestrated, and large molecular weight tracers (e.g., horseradish peroxidase) readily leak out into the surrounding interstitium following intravenous administration (Freddo et al., 1990; Vegge, 1971). Since there are no tight junctions between the pigmented cells, the aforementioned tracers have been shown to infiltrate the paracellular space between the PE and NPE cell layers (Smith and Rudt, 1975). However, the tight junctions between NPE cells act as a permeability barrier and prevent diffusion of blood-borne macromolecules (e.g. proteins) into the AH (Cunha-Vaz, 1979; Freddo, 2001). The tight junctions (Vegge, 1971) exclude large molecules from the AH (Green, 1984; Novack and Leopold, 1988). Thus, these specialized junctions constitute the most important part of the blood-aqueous barrier.

Many gap junctions usually are found between the lateral surfaces of the PE cells and less frequently between the lateral surfaces of the NPE cells. Gap junctions and puncta adherentia are located between the PE and NPE cells and between each type of cells (Fig. 7). Each gap junction channel comprises two hemichannels (connexons), each of which is composed of six radially-arranged connexins around a central pore (Scemes et al., 2007). This highly integrated epithelium in addition to the secretion of $\mathrm{AH}$, affords attachment to the ciliary zonules (Fig. 1). All ancillary functions to maintain proper transport activity, diffusion characteristics, mechanical stability of the epithelium, etc. depend upon the properties of these specialized intercellular junctions (Raviola and Raviola, 1978). AH production is only possible if the transport activity of the epithelial cells is precisely coordinated and solute gradients are not dissipated by free diffusion of water and solutes along the intercellular clefts of the epithelium. Mechanical stability is an essential prerequisite for the epithelium to withstand the tensile force of the elastic zonular fibers.

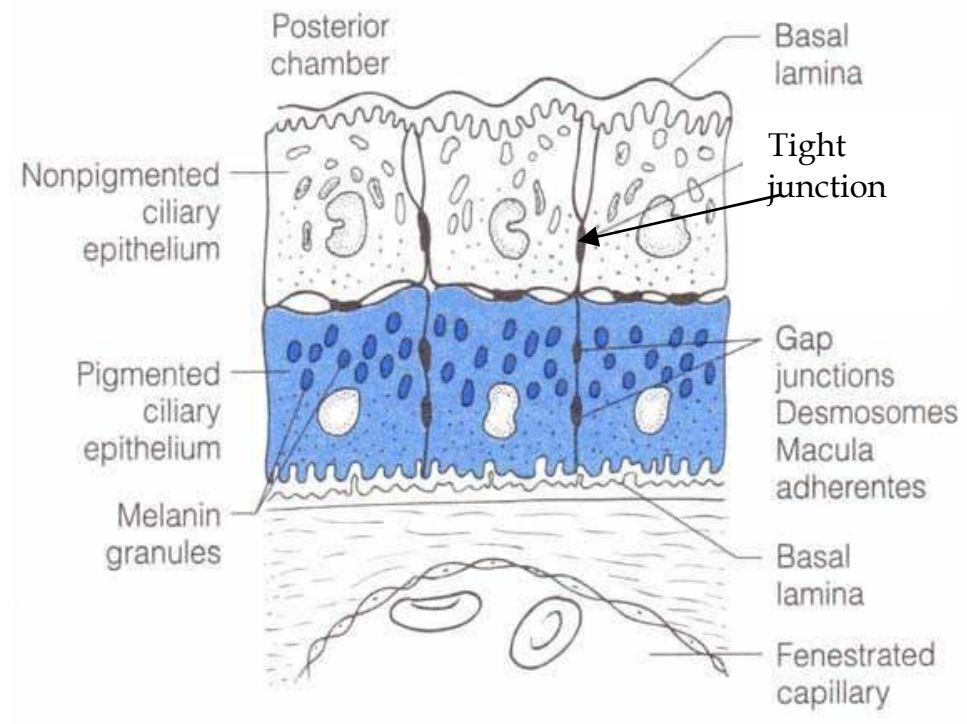

Fig. 7. Diagram of double layer ciliary epithelium showing tight and gap junctions (Forrester et al., 1996) (used with permission) 
A large number of gap junctions between both the NPE and PE cells with greater concentration at the interface between the two epithelial layers constitute a striking morphological feature of the CE. These junctions, less commonly referred to as nexuses or macula communicans, are specialized membrane proteins (connexins) that are able to form channels, which permit movement of molecules up to 1,000 daltons (Kondo et al., 2000; Saez et al., 1993). In electron micrographs of thin sections, they appear as regions of intercellular contact where apposed plasma membranes of adjacent cells are separated by a gap junction of 2 - 3nm (Saez et al., 1993). Gap junctions mediate both electrical and metabolic coupling between cells (Gilula et al., 1972; Wang et al., 2010).

\subsubsection{The blood-ocular barriers}

The striking differences between the composition of plasma and the $\mathrm{AH}$ means that substances encounter difficulty in passing from one fluid to the other. In addition, there is no barrier between the posterior chamber and the vitreous body and between the vitreous humor and the retina. Horseradish peroxidase and even Thorotrast particles can pass from the vitreous into the intercellular spaces of the retina (Smelser et al., 1965). The movement of horseradish peroxidase is halted at the tight junctions of the pigment epithelium of retina (Peyman and Apple, 1972; Peyman and Bok, 1972). Thus, to maintain the normal composition of $\mathrm{AH}$, which is distinct from the plasma, some kind of barrier must exist in all the associated structures separating the $\mathrm{AH}$, vitreous and the retina from the plasma. All such structures have either endothelial and/or epithelial barriers. In the mammalian eye, endothelial barriers are localized in the vessels of the retina, optic nerve, ciliary muscle and the iris. Epithelial barriers are present in the pigment epithelium of retina, the NPE of the ciliary body and the iridal epithelium (Raviola, 1977). These structures constitute the two important barrier systems, namely the blood-vitreous or the blood-retinal barrier and the blood-aqueous barrier. The barriers prevent almost all protein movement and they are effective even to low molecular weight solutes, such as sucrose and fluorescein (Bill, 1975).

\subsubsection{Blood-vitreous or blood-retinal barrier}

The endothelial cells of the retinal capillaries and the tight junctions between the retinal pigment epithelial cells (RPE) represent respectively the endothelial and epithelial parts of the blood-retinal barrier. They prevent both outward and inward movement of horseradish peroxidase as examined by injecting intravenously and into the vitreous (Peyman and Apple, 1972; Peyman and Bok, 1972). The epithelial part of the barrier, i. e., the RPE separates the choroidal fluid from the retinal tissue fluid and is very important because choroidal tissue fluid is likely to be very similar to plasma.

\subsubsection{The blood-aqueous barrier}

The ciliary and the iridial epithelia constitute the epithelial part of the blood-aqueous barrier and protect the posterior chamber from circulating macromolecules. The other part of the barrier is constituted by the endothelium of the iris capillaries. The endothelial cells of iris capillaries are joined by tight junctions, making the capillaries non-fenestrated. This prevents movement of macromolecules from the lumen of the iris vessels into the stroma. Horseradish peroxidase does not pass through the walls of these vessels (Vegge, 1971). 


\subsection{Molecular entities involved in AH secretion}

The molecules that are involved in AH secretion include transport proteins, enzymes and ion channels. Since the blood-ocular barriers are largely impermeable even to small water soluble substances, such as glucose and amino acids, important metabolic substrates have to be transported to the $\mathrm{AH}$ through these barriers by carrier-mediated transport systems. The carrier-mediated transport systems are specialized membrane proteins having the ability of transporting their substrates across the cell membrane either actively against their concentration gradient or passively along the electrochemical gradient. The ionic solutes, which are largely membrane impermeable, must also be transported either by different active or carrier mediated transport systems or by ion channels. Ion channels are specialized proteins spanning the cell membrane that constitute a pathway for movement of a specific ion or ions, e.g., $\mathrm{Na}^{+}$channel, $\mathrm{Ca}^{++}$channel, $\mathrm{Cl}^{-}$channel, $\mathrm{K}^{+}$channel, etc. When a particular ion channel opens it allows the ion to cross the membrane in the direction of its electrochemical gradient.

Intense research in the field of $\mathrm{AH}$ secretion over the last several decades has identified many transporter proteins/ion channels and their role in $\mathrm{AH}$ production. Most animals produce $\mathrm{AH}$ in a similar fashion, although some species differences exist, particularly in $\mathrm{Cl}^{-}$ and $\mathrm{HCO}_{3}$ - secretion (Do and Civan, 2009). Three $\alpha$ subunits isoforms $(\alpha 1, \alpha 2, \alpha 3)$ of the primary active transport system, Na,K-ATPase, have been shown to be expressed in the NPE (Ghosh et al., 1991; Shahidullah et al., 2007) with the $\alpha 1$ isoform in the PE (Ghosh et al., 1990). Na,K-ATPase is localized mainly along the basolateral infoldings and interdigitations of both the PE and NPE cells (Mori et al., 1991; Usukura et al., 1988) and higher activities were found on the NPE cells (Riley and Kishida, 1986; Usukura et al., 1988). The $\mathrm{Na}^{+}, \mathrm{K}^{+}-$ ATPase of PE cells probably differs functionally from that of NPE cells as reflected by the different isoforms shown in these two cell types (Ghosh et al., 1991). Pharmacological inhibition of $\mathrm{Na}$,K-ATPase by ouabain caused $62 \%$ inhibition of aqueous humor secretion in an arterially perfused bovine eye indicating the major role played by this primary active transport system (Shahidullah et al., 2003). Transport systems for glucose, several amino acids (DiMattio et al., 1981; Hu et al., 2011; Reddy, 1979) and ascorbate (Chu and Candia, 1988) have been identified in the NPE. Potassium channels, chloride channels, bicarbonate transporters and chloride-bicarbonate anion exchanger have also been identified and characterized in the NPE (Edelman et al., 1995; Shahidullah et al., 2009). PE has been shown to express important transport proteins, such as sodium bicarbonate co-transporter (Helbig et al., 1989a), $\mathrm{Cl}-/ \mathrm{HCO}_{3}{ }^{-}$exchange (Helbig et al., 1988a), $\mathrm{Na}^{+} / \mathrm{H}^{+}$exchange (Helbig et al., $1988 \mathrm{~b}$ ). The $\mathrm{Na}^{+}-\mathrm{K}^{+}-2 \mathrm{Cl}^{-}$-cotransporter that transports $\mathrm{Na}^{+}, \mathrm{K}^{+}$and $\mathrm{Cl}^{-}$into and out of cells in an electrically neutral manner, in most cases with a stoichiometry of $1 \mathrm{Na}^{+}, 1 \mathrm{~K}^{+}$and $2 \mathrm{Cl}^{-}$ (Haas, 1994), has been shown to express at the basolateral membrane of bovine PE (Dunn et al., 2001). In addition functional evidence of this transporter has been identified in the NPE (Crook and Polansky, 1994; Dong and Delamere, 1994). We published immunohistochemical data showing two carbonic anhydrase isoforms (CA II and CAIV) (Fig. 8) enriched in the NPE layer but sparse or absent in the PE layer (Shahidullah et al., 2009). CA II was cytoplasmic but CA IV was localized to the NPE surface, CA II and IV also were abundant in cultured NPE. Carbonic anhydrase inhibitors (CAIs) are highly effective in reducing aqueous inflow. Interestingly, transport systems for glucose (Alm, 1984; Alm et al., 1981; Dollery et al., 1971), amino acids (Miller and Steinberg, 1976), lactate (Alm and Tornquist, 1985) and choline (Karlsson et al., 1984) have also been identified in the cells constituting the blood-retinal barrier. 

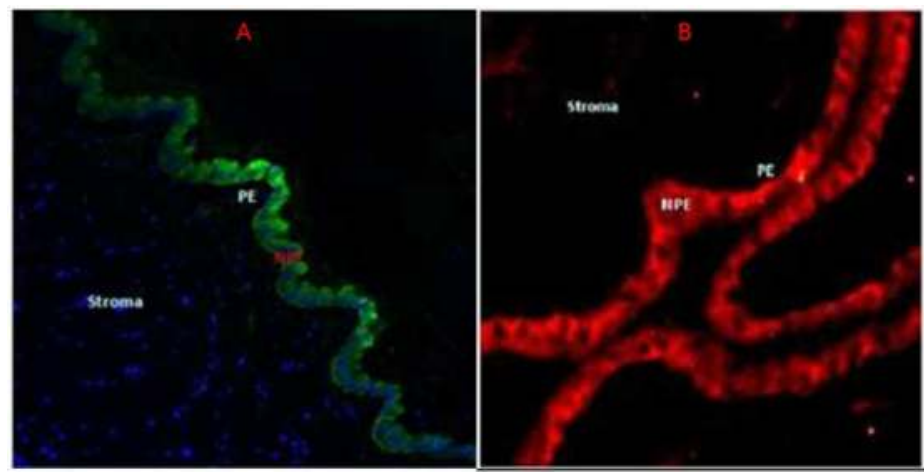

Fig. 8. Immuolocalization of CAII (A) and CAIV in porcine ciliary body (Shahidullah et al., 2009). Note that CAII is localized in the NPE cytoplasm and CAIV on the NPE membrane. (used with permission)

\subsection{Mechanism of AH secretion}

There is now general agreement that AH is produced by the double-layered CE. Three basic mechanisms, ultrafiltration, active transport and diffusion are involved, at one step or other, in the process of $\mathrm{AH}$ secretion. $\mathrm{AH}$ formation is a complex process and it can be subdivided into three steps:

1. In the first step, an ultrafiltrate is passed through the fenestrated capillaries of the ciliary processes into the ciliary stroma. Due to the fenestrated nature of the ciliary capillaries this ultrafiltrate contains a high percentage of plasma proteins. The capillary wall is a considerable barrier for some of the plasma proteins. Studies on the dynamics of extravascular plasma proteins in the ciliary processes indicate that the net filtrate from the capillaries contain about $4 \%$ of the albumin and $3 \%$ of the $\gamma$-globulin in the plasma (Bill, 1968a). The protein content in the ciliary stroma may be extremely high in some species, e.g. in rabbit it is about $75 \%$ of that in the plasma (Bill, 1968b). The high protein concentration in the ciliary stroma reduces the transcapillary difference in the oncotic pressure, which is important for filtration from the capillaries.

2. In the second step, a number of solutes are transported from the ultrafiltrate to the posterior chamber across the CE bilayer. This step is considered as the extraction of materials (electrolytes and other substances, such as glucose, amino acids, ascorbate, etc.) by the CE bilayer, against a concentration gradient, by means of diffusion, active or carrier-mediated secretion of solutes (Cole, 1977). Blood-borne large molecules, such as proteins cannot pass the blood-aqueous barrier (Green, 1984; Novack and Leopold, 1988). The ocular barriers are effective even with respect to low molecular weight solutes, such as sucrose and fluorescein (Bill, 1975).

3. In the third step the osmotic gradient established by the active transfer and accumulation of ions and other solutes into the posterior chamber (step 2) facilitates the passive flow of water into the posterior chamber by osmosis (Bill, 1975; Brubaker, 1991).

\subsection{1 lons and solutes transport across the CE}

Transfer of ions and solutes from the ciliary stroma to the posterior chamber requires that the solutes will pass across both the PE and NPE layers. There are still unanswered questions 
about the functions of each specific cell layers and their interactions. The presence of a large number of gap junctions between the PE and NPE suggests a coupling of these two layers in transepithelial transport (Coca-Prados et al., 1992; Helbig et al., 1989b; Wang et al., 2010). One of the characteristics of the $\mathrm{CE}$ is the asymmetric distribution of ion transporters on the membranes of PE and NPE cells, which is essential for mediating the vectorial ion and solute transport. Several models have been suggested for ion and solute movement (Avila et al., 2002; Civan and Macknight, 2004; Do and To, 2000; Jacob and Civan, 1996; To et al., 2002). No unified model has been proposed. However, the consensus is that there are at least three transport steps involved in transferring ion and/or solute across the CE:

1. Loading of ions and/or solutes from the ciliary stroma (blood) into the PE cells across its basolateral border

2. Translocation of ions and/or solutes through the gap junctions into the NPE cells

3. Shifting of ions and/or solutes from the NPE cells to the posterior chamber driven by an electrochemical gradient and/or by active or carrier-mediated transport.

Loading of major ions through the PE basolateral membrane has been proposed to occur through Na-K-2Cl cotransporter (Edelman et al., 1994; Kong et al., 2006), sodium bicarbonate cotransporter (Helbig et al., 1989a) and paired activity of $\mathrm{Na}^{+} / \mathrm{H}^{+}$and $\mathrm{Cl}-/ \mathrm{HCO}_{3}{ }^{-}$antiports (Civan and Macknight, 2004; Counillon et al., 2000). Gap junctions both within each of PE and NPE and between PE and NPE layers allow free exchange of metabolites and ions and provide direct electrical coupling between these cells (Raviola and Raviola, 1978). In accordance, gap junction dye coupling between the two cell layers has been demonstrated using intra injection of the fluorescent dye, Lucifer yellow (Oh et al., 1994; Wang et al., 2010). In addition, the fact that there is no difference in membrane potential (Carre et al., 1992; Wiederholt and Zadunaisky, 1986) and intracellular ion contents (Bowler et al., 1996) between PE and NPE cells indicates that the gap junctions allow direct intercellular communication that facilitates the two cell layers functioning as a syncytium. Thus, active transport in AH secretion applies largely to NPE. Secretion by the NPE is accomplished by the active/carrier-and channel mediated transport of one or more ions, such as $\mathrm{Na}^{+}, \mathrm{Cl}^{-}$, $\mathrm{HCO}_{3}^{-}$, and low molecular weight solutes, such as amino acids, glucose, inositol, ascorbic acid, etc. The concentration of ascorbic acid in the aqueous is about 20 times that in the plasma and there is evidence that it is transported actively to the AH (Becker, 1967; Chu and Candia, 1988). A schematic diagram of demonstrating the different junctions, transporters and pump located within the PE and NPE membrane is shown (Fig. 9)

\section{Composition of the aqueous humor}

$\mathrm{AH}$ has a unique composition that differs from plasma in several important aspects. Several laboratory studies confirm that $\mathrm{AH}$ is not simply a filtrate. It is an intraocular fluid, homeostatically controlled and some of which individual components are in rapid turnover. The $\mathrm{AH}$ is composed of ions $\left(\mathrm{Na}^{+}, \mathrm{K}^{+}, \mathrm{Ca}^{2+}, \mathrm{Mg}^{2+}, \mathrm{Cl}, \mathrm{HCO}_{3}^{-}\right)$, crystalloid or low molecular weight substances (glucose, ascorbate, lactate, pyruvate, urea, $\mathrm{H} 2 \mathrm{O} 2$, amino acids, etc.), colloidal or high molecular weight substances, such as proteins (Borazan et al., 2010; Browne et al., 2011; Ghanem et al., 2011; Lim et al., 2010), lipids (Jahn et al., 1983), biologically active substances (catecholamines, eicosanoids, hormones, etc.) as well as some miscellaneous substances such as hyaluronic acid, hyaluronidase, etc.). These components derive from a number of sources, the principal ones being the plasma (by passive diffusion) and the $\mathrm{CE}$ (by active secretion). Specific substances also enter the AH by diffusion or secretion from 


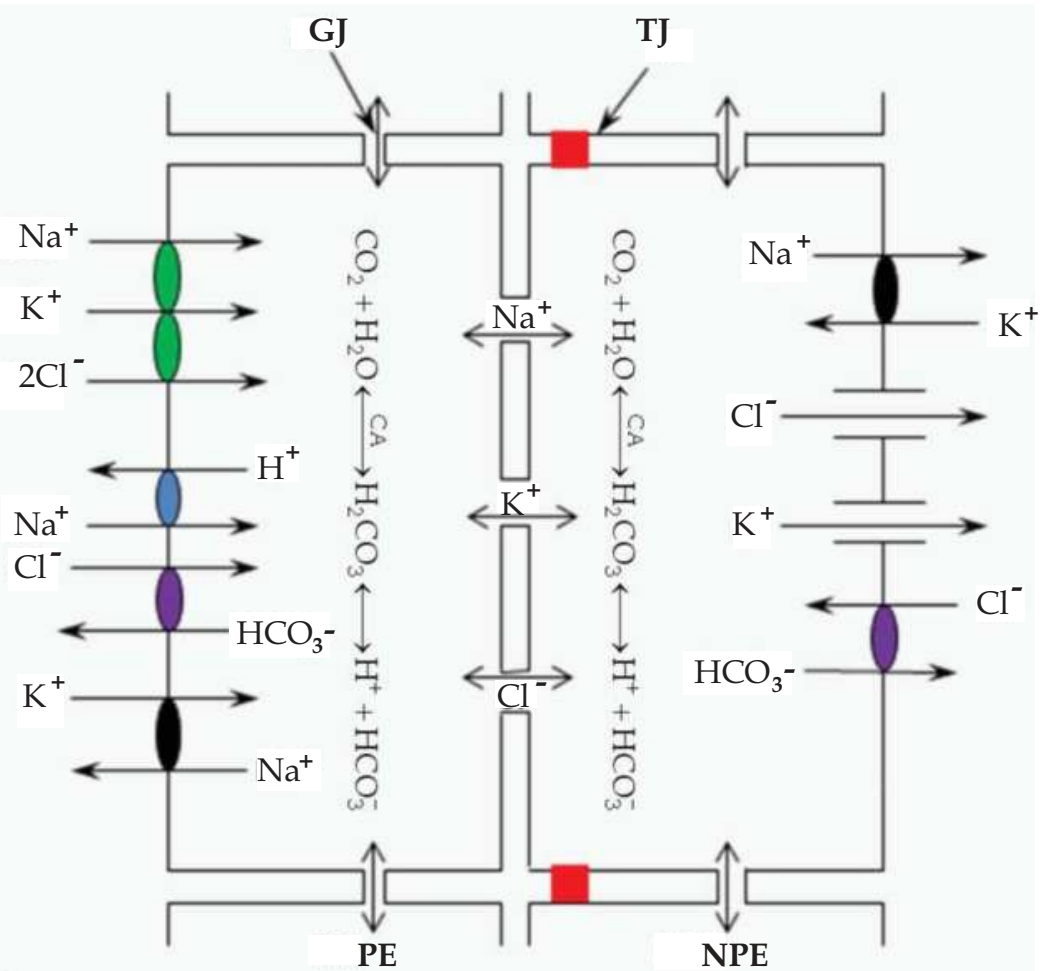

Fig. 9. Schematic diagram of a PE and NPE duplet showing locations of gap junctions, tight junctions, major transporters and ion channels on the membrane, together with the direction of transport of their substrates. PE, pigmented ciliary epithelium; NPE, nonpigmented ciliary epithelium; GJ, gap junction; TJ, tight junction. Note that the gap junctions between the PE and NPE as well as between each type of cells allow free passage of ions and other solutes (double-headed arrows)

surrounding tissues: corneal endothelium, crystalline lens, trabecular meshwork, iris and vitreous. These tissues utilize a number of nutrients present in the $\mathrm{AH}$, e.g. the main source of glucose for the cornea and the lens is the AH. Thus, the composition of $\mathrm{AH}$ depends on the nature of the secreted fluid from the $\mathrm{CE}$ plus the subsequent passive and active exchange across adjacent tissues. The rate of turnover of $\mathrm{AH}$ also contributes to modulation of the composition by accumulating waste products from the surrounding tissues. Alterations of the $\mathrm{AH}$ occur continually. For example the lens alters the $\mathrm{AH}$ by using glucose, amino acids and other solutes and releasing metabolic wastes, such as lactic acid. It may also act as homeostatic reservoir for amino acids. The normal composition of $\mathrm{AH}$ reflects the normality of all the associated structures contributing in $\mathrm{AH}$ production and drainage.

The composition of AH can be modulated by many factors. The imbalances in the carefully tuned chemical composition of $\mathrm{AH}$ are thought to be both the cause and consequences of pathological conditions in the anterior segment. Biochemical analysis of $\mathrm{AH}$ has identified 
high molecular weight lens proteins as a cause of elevated IOP in phacolytic glaucoma, i.e., sudden onset of open-angle glaucoma caused by a leaking mature or hypermature (rarely immature) cataract (Epstein et al., 1978) and ascorbic acid concentration in AH differs in normal subjects and in Chronic Open Angle Glaucoma (COAG) patients (Lam and Lee, 1975). Several studies have shown that AH can promote proliferation of cells in tissue culture (Albrink and Wallace, 1951; Benezra and Sachs, 1974; Herschler et al., 1980; Herschler and Tucson, 1983) or inhibit cellular growth (Kornblueth and Tenenbaum, 1956). While these opposing findings may perhaps be explained by the different experimental conditions and procedures, the possibility of $\mathrm{AH}$ being a growth modulator is a real possibility since a number of growth factors are present in the AH (Borazan et al., 2010; Browne et al., 2011; Ghanem et al., 2011; Lim et al., 2010). AH may be thought of as a growth medium in which stimulatory agents and cytotoxic factors act to affect changes in cell number, morphology and function. Understanding the nature of these cell growth modulators and their functions may provide a clue to solving certain problems in glaucoma. It is possible that derangement of such a modulator system in the $\mathrm{AH}$ may lead to changes in the proliferative capacity, biosynthetic properties and ultimately the survival of the cells of the trabecular meshwork resulting in an increased resistance to outflow. Tables 1, 2 and 3 show normal concentration of some of the important components of $\mathrm{AH}$ and plasma.

\begin{tabular}{||l|l|l||}
\hline \hline Components & Aqueous Humor (ng.ml-1) & Plasma (ng.ml-1) \\
\hline \hline Prostaglandins & 2 & - \\
\hline Cyclic AMP & 8 & - \\
\hline Catecholamines & & \\
\hline Noradrenaline & $\mathrm{a} 0.8-1.14$ & 0.311 \\
\hline Adrenaline & $0-0.13$ & 0.097 \\
\hline Dopamine & 0.12 & 0.037 \\
\hline
\end{tabular}

Adapted from: (Cooper et al., 1984) ; a(Trope and Rumley, 1985).

Table 1. Biologically active substances in AH and plasma

\begin{tabular}{|l|l|l|}
\hline Components & AH $\left(\mu \mathrm{g} \cdot \mathrm{ml}^{-1}\right)$ & Plasma $\left(\mu \mathrm{g} \cdot \mathrm{ml}^{-1}\right)$ \\
\hline \hline Protein (total) & $\mathrm{a} 12.4 \pm 2.0$ & 7000 \\
\hline Albumin & $\mathrm{b} 5.5-6.5$ & 3400 \\
\hline Transferrin & $\mathrm{b} 1.3-1.7$ & - \\
\hline Prealbumin & $\mathrm{b} 0.3-0.4$ & - \\
\hline Fibronectin & $\mathrm{c} 0.25$ & 29 \\
\hline Immunoglobulins & & \\
\hline IgG & $\mathrm{c} 3.0$ & 1270 \\
\hline IgE (Iu.ml-1) & $\mathrm{c}<0.75$ & $16-218$ \\
\hline
\end{tabular}

Sources: a(Tripathi et al., 1989); b(Inada et al., 1984); c(Berman, 1991)

Table 2. Protein composition of $\mathrm{AH}$ in comparison to plasma 


\begin{tabular}{|l|l|l|}
\hline \hline Components & Aqueous Humor $(\mathrm{mM})$ & Plasma $(\mathrm{mM})$ \\
\hline \hline $\mathrm{Na}^{+}$ & 142 & $130-145$ \\
\hline $\mathrm{K}^{+}$ & 4 & $3.5-5.0$ \\
\hline $\mathrm{Ca}^{2+}$ & 1.2 & $2.0-2.6$ \\
\hline $\mathrm{Mg}^{2+}$ & 1 & $0.7-1.1$ \\
\hline $\mathrm{Cl}^{+}$ & 131 & $92-125$ \\
\hline $\mathrm{HCO}^{-3}$ & 20 & $24-30$ \\
\hline Ascorbate & 1.1 & $0.04-0.06$ \\
\hline Lactate & 4.5 & $0.5-0.8$ \\
\hline Citrate & 0.1 & 0.1 \\
\hline Glucose & $2.7-3.9$ & $5.6-6.4$ \\
\hline Urea & 4.1 & $3.3-6.5$ \\
\hline Glutathione & $0.001-0.01$ & - \\
\hline${ }^{a}{ }_{2} \mathrm{O}_{2}$ & $0.024-0.069$ & - \\
\hline bAmino acids (total) & 0.17 & 0.12 \\
\hline
\end{tabular}

Adapted from: (Riley, 1983); a(Spector and Garner, 1981); b(Davson, 1969)

Table 3. Electrolytes and low molecular weight solutes in human AH and plasma

\section{Regulation of AH secretion}

The rate of $\mathrm{AH}$ flow varies according to a circadian rhythm with different rates of flow during day time and night (Koskela and Brubaker, 1991; McCannel et al., 1992; Reiss et al., 1984; Topper and Brubaker, 1985). In healthy human volunteers it has been shown that the night time seated rate of AH flow, fluorophotometric outflow and seated IOP was reduced by 49,45 and $16 \%$ respectively (Liu et al., 2011). The night time flow rate can be increased by administration of exogenous epinephrine (Topper and Brubaker, 1985) but cannot be reduced by administration of timolol (McCannel et al., 1992; Topper and Brubaker, 1985) even though it can further be reduced by acetazolamide, a CA inhibitor (McCannel et al., 1992; Topper and Brubaker, 1985). These seminal findings indicate that the AH flow is under adrenergic control. Current opinion on the regulation of $\mathrm{AH}$ dynamics has been stated as follows: "the pharmacotherapy of glaucoma is based mainly on neuro-hormonal processes controlling aqueous humor dynamics. Systemic hormones as well as local hormones and autonomic nervous system mediators are involved in the processes of aqueous humor formation and drainage. Anti-glaucoma medications act mainly through activation or inhibition of these systems' receptors, assisting to decrease aqueous humor production or improve aqueous humor outflow" (Terelak-Borys and Liberek, 2007a; Terelak-Borys and Liberek, 2007b). The presence of $\beta$-adrenergic receptors in the ciliary process of rabbit (Bromberg et al., 1980), ox (Polansky et al., 1985) and human has been demonstrated (Wax and Molinoff, 1987). Other studies have revealed that the $\beta$-adrenergic receptors are predominantly $\beta 2$-subtype (Crook and Riese, 1996; Elena et al., 1984; Nathanson, 1980; Wax and Molinoff, 1987). The administration of timolol, a $\beta$-adrenergic antagonist, either systemically or topically reduces $\mathrm{AH}$ formation and lowers IOP in normal human subjects (Coakes and Brubaker, 1978; Dailey et al., 1982; Katz et al., 1976) 
and animals (Shahidullah et al., 1995; Watanabe and Chiou, 1983). Clinical treatment of glaucoma has been most successfully directed towards reducing $\mathrm{AH}$ formation with $\beta$-blockers.

\section{Drainage of aqueous humor}

$\mathrm{AH}$ enters the posterior chamber from the ciliary process and flows around the lens and through the pupil into the anterior chamber (Fig. 1). From the anterior chamber AH leaves the eye and enters the general venous circulation by bulk flow by two exit pathways, both commencing at the anterior chamber angle (Johnson, 2005; Lei et al., 2011; Nilsson, 1997; Sihota, 2011).

\subsection{The anterior, trabecular or conventional route}

This pathway employs through the trabecular meshwork across the inner wall of Schlemm's Canal and then into collector channels, aqueous veins and the anterior ciliary veins. Schlemm's Canal, also known as Canal of Schlemm or the scleral venous sinus, is a circular channel. The canal is essentially an endothelium-lined circular space, resembling a lymphatic vessel and located at the limbus, i.e., the joining point of the cornea and sclera. The inner side of the canal is formed by 3 layers of the trabecular meshwork. The first layer is the uveal meshwork, which is the forward extension of the ciliary muscle inserting in the cornea (Bill and Svedbergh, 1972). The second layer is constituted by several sheets of connective tissue extending between the scleral spur and the peripheral cornea. The third layer, called the juxtacanalicular tissue, is an endothelial meshwork and the inner wall of Schlemm's Canal. It is composed of collagen and elastic fibers, a ground substance and several layers of endothelium enmeshed in a matrix of glycosaminoglycans, proteoglycans and other macromolecules. The major resistance site to outflow is thought to be at the juxtacanalicular tissue (also called cribriform plexus) and the inner wall of Schlemm's Canal.

\subsection{The posterior, uveoscleral or unconventional route}

The second pathway of $\mathrm{AH}$ outflow is the posterior, uveoscleral or unconventional route (Johnson, 2005; Nilsson, 1997). Aqueous flows from the chamber angle across the iris root and the anterior face of the ciliary muscle, through the connective tissue spaces between the muscle bundles of the ciliary body. These spaces open into the suprachoroid from which fluid can pass through the sclera or the perivascular spaces into the episcleral tissue and then into the venous circulation. The pressure in the suprachoroid space is lower than in the anterior chamber by at least a few mmHg under normal conditions, thus, favoring this flow. In primates most of the drainage occurs through the trabecular route and a small portion is drained via the uveoscleral route. A small part of the aqueous humor flows into the vitreous to be absorbed into the posterior part of the eye; some of the aqueous apparently is absorbed by the ciliary body (Moses, 1990). In lower animals the Canal of Schlemm is absent but they have a sinus structure with the same function (Bill, 1975). In human eyes, the uveoscleral outflow accounts for about 5 to 20 percent of total outflow (Bill, 1975; Bill and Phillips, 1971), while in monkey, the outflow is fairly equally distributed between the two routes (Bill, 1966a; Bill and Phillips, 1971). In rabbit and cat, there is comparatively little uveoscleral drainage (Bill, 1966b; Cole and Monro, 1976). 
The flow of aqueous through the different compartments and outflow pathways is a typical hydraulic flow, where the source of energy is the pressure difference at the ends of the passage; the pressure at the upstream end is greater. The difference of upstream and downstream pressure is called pressure head $(\Delta \mathrm{P})$. The rate of hydraulic flow is related to Poiseuille's law. It has been incorporated into the Goldman equation:

$$
\mathrm{F}=\mathrm{C}(\mathrm{P}-\mathrm{P}) \text { or } \mathrm{F}=\Delta \mathrm{P} . \mathrm{C}
$$

This equation relates aqueous flow $(\mathrm{F})$ to facility of outflow $(\mathrm{C})$ and $\Delta \mathrm{P}$, the pressure head is the difference between IOP $(\mathrm{P})$ and the episcleral venous pressure $\left(\mathrm{P}_{\mathrm{e}}\right)$, i.e. the pressure in the vessels into which $\mathrm{AH}$ drains. The mean normal value for outflow facility in human is estimated to be $0.25 \mu \mathrm{l} \cdot \mathrm{min}^{-1} \cdot \mathrm{mmHg}^{-1}$ of the applied pressure (Davson, 1990)

\section{The intraocular pressure}

The intraocular pressure (IOP) is the hydrostatic pressure exerted by the $\mathrm{AH}$. The mean normal IOP in man is about $15 \mathrm{mmHg}$ with the highest and lowest accepted values of 21 $\mathrm{mmHg}$ and $10.5 \mathrm{mmHg}$ respectively (Davson, 1990; Hurvitz et al., 1991). IOP can vary between species, individual and even between eyes of the same individual. This pressure is governed by several factors, such as the rate of secretion of $\mathrm{AH}$, resistance to outflow (by at least 2 pathways) and episcleral venous pressure. Despite the fact that IOP is the most important risk factor of glaucoma and that control for IOP, either by pharmacological agents or by surgery, remains the only effective glaucoma treatment, our mechanistic understanding of IOP regulation in the eye is limited. Proper functioning of the outflow pathways plays an important role in the regulation of IOP. Some of the important factors, identified or proposed, include age, alterations of extracellular matrix, oxidative stress and abnormal function of certain genes.

\section{Glaucoma}

Glaucoma is a multi-factorial ocular disease/syndrome with characterised by progressive damage or degeneration to the optic nerve and visual field loss. Although increased intraocular pressure is usually present, patients with normal range IOP can also develop glaucoma. The definition published by the international consensus panel in 2002 has now been widely accepted (Foster et al., 2002; Quigley, 2011). It is defined as optic neuropathy characterized by damage to the optic nerve and visual field loss. The vision loss is progressive and irreversible and results from retinal ganglion cell (RGC) death. The disease progression is expressed by gradual deformation of the optic nerve head (optic disc), the site where ganglion cell axons exit the eye.

\subsection{Classification of glaucoma}

Currently, glaucoma is classified into primary and secondary. In primary glaucoma, the optic neuropathy is the consequence of primary defects in the circulating pathway of $\mathrm{AH}$ or within the neural retina or the ganglion cells themselves, i.e., a glaucoma not caused by another eye or medical condition. In secondary glaucoma, the optic neuropathy or glaucomatous symptoms occur due to some other ocular or systemic disease or defects.

Major types of primary glaucoma: 
1. Primary open angle glaucoma (POAG)/chronic open angle glaucoma (COAG): Currently the idea that high IOP is the exclusive cause of optic neuropathy has been almost discarded, since in many patients optic neuropathy occurs at normal IOP (Foster et al., 2002; Quigley, 2011). POAG is now defined as significant optic nerve damage in an eye, which does not have evidence of angle closure on gonioscopy, and where there is no identifiable secondary cause. POAG is the most prevalent type of glaucoma.

2. Primary closed angle glaucoma (PCAG): Patients having narrow or closed anterior chamber angle associated with significant obstruction of trabecular meshwork and glaucomatous optic neuropathy. PCAG can be subdivided into subacute, acute, chronic, symptomatic or asymptomatic according to the nature and severity of the onset. The worldwide prevalence of PCAG is about one third of the rest (Quigley and Broman, 2006)

Secondary glaucoma may occur under many ocular or systemic conditions including:

1. Uveitis

2. Ocular trauma

3. Ocular neovascularization

4. Thyroid orbitopathy

In addition, there are several forms of congenital or hereditary glaucoma, which can be either primary or secondary. Moreover, there are cases where glaucomatous damage occurs without any increase in IOP, the so-called normal tension or low tension glaucoma.

\subsection{Causes of glaucoma}

Glaucoma is an age-related condition. There may be no single cause of glaucoma. Some important risk factors have so far been identified. Elevated intraocular pressure is the most important risk factor. Glaucoma is commonly, but not exclusively, associated with an increase in intraocular pressure (IOP) and optic nerve damage may be a response to chronically elevated IOP and mechanical deformation (Hernandez, 2000; Johnson et al., 1996). Treatments that lower IOP either delay or prevent progression of glaucoma (Leske et al., 2003). There is a correlation between IOP and the likelihood of development of glaucoma and its progression (Boland and Quigley, 2007). Other risk factors are age (Tschumper and Johnson, 1990); family history, ethnicity or genetic variation (Jiao et al., 2009; Rao et al., 2011); other ocular or systemic disease, such as myopia, uveitis, decreased corneal or choroidal thickness, thyroid abnormality, sleep apnea, migraine (Boland and Quigley, 2007; Foster et al., 2002); vacular factors (Yanagi et al., 2011) and others. Age plays an important role in the development of glaucoma. The phagocytosis of the trabecular meshwork is decreased or lost in older individual leading to accumulation of toxic molecules within the drainage channels causing interference with AH flow (Tschumper and Johnson, 1990).

\subsection{Pathogenesis of glaucoma}

The principal pathology of glaucoma is the atrophy of the optic nerve and visual field loss. The exact mechanism of death of ganglion cells is not known. There are a number of hypotheses on the mechanism of ganglion cell injury in glaucoma. One hypothesis is the compromised blood supply to the optic nerve due to mechanical compression exerted by high IOP. There is evidences that suggests tissue hypoxia in the retina may affect the survival ganglion cells (He et al., 2011; Tezel and Wax, 2004). Other hypothesis includes oxidative or nitrative stress, both at the level of trabecular meshwork (Sacca et al., 2007) and 
retinal ganglion cells (Aslan et al., 2008; Tezel, 2006); autoimmune reactions in which an individual's immune system facilitate somatic/axonal degeneration of retinal ganglion cells (Wax and Tezel, 2009); glutamate toxicity (Vorwerk et al., 1999); loss of neurotrophic factors (Pease et al., 2000), etc. However, a various combination of these factors may be involved.The glial cells in the optic nerve head region (lamina cribrosa cells) (Quill et al., 2011), and in particular the astrocytes, the principal glial cells, have been proposed to play an important role in the glaucomatous change in the extracellular matrix in around the ganglion cells (Hernandez, 2000; Hernandez et al., 2008). In primates, alterations in the expression of metalloproteinases (MMPs) and their inhibitors (TIMPs) occur in the optic nerve head of experimental glaucoma (Agapova et al., 2003a). These changes, which are likely to contribute to remodeling of the glaucomatous optic nerve head, are particularly prominent in the optic nerve head astrocytes (Agapova et al., 2001). Altered protein expression, such as MMP1 and MT1-MMP, was also reported in human glaucomatous optic nerve head astrocytes (Agapova et al., 2003b). In the CNS, injury or stress causes normally quiescent astrocytes to become reactive, displaying altered morphology and protein expression, most notably increased glial fibrillary acidic protein (GFAP) (Gadea et al., 2008). Astrocytes are known to respond to a number of different stresses including injury (Laird et al., 2008), endothelin-1 (He et al., 2007), oxygen-glucose deprivation (Gao et al., 2008) and it is possible that such stress factors cause astrocytes to become reactive.

\subsection{Medical treatment of glaucoma}

Although the history of medical treatments dates back to 1862, all the effective treatments were developed only in the last several decades (Realini, 2011). Until now, five major classes of drugs have been used. Some of these drugs reduce IOP by reducing the secretion of $\mathrm{AH}$ and others increasing the outflow. Some have a dual effect. All the preparations are available for topical use. Greater details of these drugs have been given in two recent reviews (Lee and Goldberg, 2011; Realini, 2011). The five classes of drugs are:

1. Adrenergic agonists: The two important drugs in this group are the $\alpha-2$ adrenergic receptor agonists apraclonidine and brimonidine. These two drugs are still available in the market and are used by many patients. Brimonidine is preferable to aprachlonidine because it is a more specific agonist to $\alpha 2$ adrenoceptor. Brimonidine has been shown to produce initial reduction in $\mathrm{AH}$ secretion and in chronic administration an increase in uveoscleral outflow (Wax and Tezel, 2009). A neuroprotective effect of brimonidine has also been suggested (Wheeler et al., 2003). The use of brimonidine in children is contraindicated due to its systemic side effect and its use in adults is limited by its ocular side effects such as allergy (Rahman et al., 2010). The relatively specific $\alpha 2$ adrenergic agonist, apraclonidine, is reported to reduce both $\mathrm{AH}$ formation and outflow resistance (Gharagozloo et al., 1988; Robin, 1988).

2. Beta-adrenergic antagonists: Important drugs in this group include timolol, levobunolol, metipranolol, cartiolol and betaxolol. These drugs works by reduce $\mathrm{AH}$ secretion (Brooks and Gillies, 1992; Dailey et al., 1982; Hurvitz et al., 1991; Shahidullah et al., 1995). Although these drugs have been largely replaced as first line therapy by prostaglandin analogs, they are still used in many cases. Timolol and metipranolol have been claimed to be neuroprotective (Wood et al., 2003).

3. Parasympathomimetics: Important drugs in this group include pilocarpine, carbachol and echothiphate iodide. Parasympathomimetics increase the outflow of aqueous 
humor through the trabecular meshwork. They produce contraction of the iris sphincter and ciliary muscle, which opens the trabecular lamellae. Pilocarpine and carbachol interact directly with the muscarinic receptors of the ciliary muscle whereas echthiophate iodide interacts indirectly by inhibiting cholinesterase (Harris et al., 1973).

4. Carbonic anhydrase inhibitors: Carbonic anhydrase (CA) inhibitors reduce $\mathrm{AH}$ secretion rate (Larsson and Alm, 1998; Maren, 2000; Maren and Conroy, 1993; Maus et al., 1997; Vanlandingham et al., 1998; Wang et al., 1991). Acetazolamide was the first systemic CA inhibitors appeared in the early 50's. Useful topical CA inhibitors used extensively in the past and are still in use includes dorzolamide (marketed as Trusopt by Merck) and brinzolamide (marketed as Azopt by Alcon Laboratories). CA inhibitors are very effective drugs in reducing $\mathrm{AH}$ secretion but their mechanism is poorly understood. CA inhibitors reduce the availability of substrate $\left(\mathrm{HCO}_{3}^{-}\right)$for anion exchanger-2 (AE2)-mediated blood-to-aqueous bicarbonate transport. Acetazolamide reduces the rate of blood-to-aqueous ${ }^{14} \mathrm{C}$-labelled bicarbonate movement (Zimmerman et al., 1976). This is in accordance with their ability to reduce AH formation in dogs (Maren, 1976) and rabbits (Caprioli and Sears, 1984; Kodama et al., 1985), species in which the $\mathrm{CE}$ concentrates bicarbonate from blood to aqueous and the $\mathrm{AH}$ is bicarbonate-rich. Curiously, however, the CAIs reduce aqueous formation equally efficiently in eyes where the concentration of bicarbonate in plasma and aqueous is similar in human (Dailey et al., 1982; Toris et al., 2004), monkey (Wang et al., 1991), bovine (Shahidullah et al., 2003) and pig (Shahidullah et al., 2009). There is no apparent net bicarbonate movement across the CE in these species, yet the CAIs reduce fluid formation. Thus, the mechanism of CAI is still unknown.

5. Prostaglandins: Prostaglandin F2 $\alpha$ analogs are the newest class of drugs and are most effective drugs discovered so far. Among the available drugs in this group, the most effective ones include latanoprost (marketed as Xalatan by Pharmacia in 1996, later acquired by Pfizer), travoprost (Travatan, Alcon) and bimatoprost (Lumigan, Allergan). The effects on IOP and AH dynamics of these drugs are similar. They consistently produce substantial increase uveoscleral outflow and a less consistent finding is an increase in trabecular outflow (Toris et al., 2008).

\section{Conclusion and future direction}

The principal pathological lesion in glaucoma is the degeneration of ganglion cell axons and eventually the ganglion cell bodies. The proven treatments available are effective only in lowering the IOP, one of the most important risk factors of glaucoma. However, glaucoma damage also presents in patients displaying normal IOP (low tension or normal tension glaucoma). It must be recognized that IOP lowering drugs are not curative, even though they delay or in some cases prevent progression of the disease. Thus, future research should be directed towards exploring the exact causes of optic nerve damage or ganglion cell death. Recent studies have suggested some role of the glial cells, such as, lamina cribrosa cells (Quill et al., 2011) and astrocytes (Hernandez, 2000; Hernandez et al., 2008), in the remodeling of the extracellular matrix in the optic nerve head. How these cells and remodeling of the region plays role in causing ganglion cell death is unclear. Better mechanistic understanding of the optic nerve damage and ganglion cell death is crucial to 
development of curative treatment of glaucoma based on neuroregeneration rather than neuroprotection.

\section{References}

Agapova OA, Kaufman PL, Lucarelli MJ, Gabelt BAT, Hernandez MR. 2003a. Differential expression of matrix metalloproteinases in monkey eyes with experimental glaucoma or optic nerve transection. Brain Research 967(1-2):132-143.

Agapova OA, Ricard C, S. , Salvador-Silva M, Hernandez MR. 2001. Expression of matrix metalloproteinases and tissue inhibitors of metalloproteinases in human optic nerve head astrocytes. Glia 33(3):205-216.

Agapova OA, Yang P, Wang WH, Lane DA, Clark AF, Weinstein BI, Hernandez MR. 2003b. Altered expression of 3 alpha-hydroxysteroid dehydrogenases in human glaucomatous optic nerve head astrocytes. Neurobiology of Disease 14(1):63-73.

Alm A. 1984. Kinetics of glucose transport across the blood-retinal barrier. Investigative Ophthalmology \& Visual Science 25(4):491-493.

Alm A., Tornquist P. 1985. Lactate transport through the blood-retinal and the blood-brain barrier in rats. Ophthalmic Research 17(3):181-184.

Alm A., Tornquist P, Maepea O. 1981. The uptake index method applied to studies on the blood-retinal barrier. II. Transport of several hexoses by a common carrier. Acta Physiologica Scandinavica 113(1):81-84.

Aslan M, Cort A, Yucel I. 2008. Oxidative and nitrative stress markers in glaucoma. Free Radical Biology \& Medicine 45(4):367-376.

Avila MY, Seidler RW, Stone RA, Civan MM. 2002. Inhibitors of NHE-1 Na+/H+ exchange reduce mouse intraocular pressure. Investigative Ophthalmology \& Visual Science 43(6):1897-1902.

Becker B. 1967. Ascorbate transfer in guinea pig eyes. Invest Ophthalmol Vis Sci 6:410.

Berman ER. 1991. Aqueous, Iris-ciliary Body and Trabeculum: In Biochemistry of the Eye. New York, London: Plenum. 151-200 p.

Bill A. 1966a. Conventional and uveo-scleral drainage of aqueous humour in the cynomolgus monkey (Macaca irus) at normal and high intraocular pressures. Experimental Eye Research 5(1):45-54.

Bill A. 1966b. The routes for bulk drainage of aqueous humour in rabbits with and without cyclodialysis. Documenta Ophthalmologica 20(4):157-169.

Bill A. 1968a. Capillary permeability to and extravascular dynamics of myoglobin, albumin and gammaglobulin in the uvea. Acta Physiologica Scandinavica 73(1):204-219.

Bill A. 1968b. A method to determine osmotically effective albumin and gammaglobulin concentrations in tissue fluids, its application to the uvea and a note on the effects of capillary "leaks" on tissue fluid dynamics. Acta Physiologica Scandinavica 73(4):511-522.

Bill A. 1975. Blood circulation and fluid dynamics in the eye. Physiological Reviews 55(3):383-417.

Bill A., Phillips CI. 1971. Uveoscleral drainage of aqueous humour in human eyes. Experimental Eye Research 12(3):275-281.

Bill A., Svedbergh B. 1972. Scanning electron microscopic studies of the trabecular meshwork and the canal of Schlemm--an attempt to localize the main resistance to outflow of aqueous humor in man. Acta Ophthalmologica 50(3):295-320. 
Boland MV, Quigley HA. 2007. Risk factors and open-angle glaucoma: classification and application. Journal of Glaucoma 16(4):406-418.

Borazan M, Karalezli A, Kucukerdonmez C, Bayraktar N, Kulaksizoglu S, Akman A, Akova YA. 2010. Aqueous humor and plasma levels of vascular endothelial growth factor and nitric oxide in patients with pseudoexfoliation syndrome and pseudoexfoliation glaucoma. Journal of Glaucoma 19(3):207-211.

Bowler JM, Peart D, Purves RD, Carre DA, Macknight AD, Civan MM. 1996. Electron probe X-ray microanalysis of rabbit ciliary epithelium. Experimental Eye Research 62(2):131-139.

Bromberg BB, Gregory DS, Sears ML. 1980. Beta-adrenergic receptors in ciliary processes of the rabbit. Investigative Ophthalmology \& Visual Science 19(2):203-207.

Bron AJ, Tripathi RC, Tripathi BJ, editors. 1997. Wolff's Anatomy of the Eye and Orbit. Eight ed. London, Whwinheim, New York, Tokyo, Melbourne, Madras: Chapman and Hall Medical. 736 p.

Brooks AM, Gillies WE. 1992. Ocular beta-blockers in glaucoma management. Clinical pharmacological aspects. Drugs \& Aging 2(3):208-221.

Browne JG, Ho SL, Kane R, Oliver N, Clark AF, O'Brien CJ, Crean JK. 2011. Connective tissue growth factor is increased in pseudoexfoliation glaucoma. Investigative Ophthalmology \& Visual Science 52(6):3660-3666.

Brubaker RF. 1991. Flow of aqueous humor in humans [The Friedenwald Lecture]. Investigative Ophthalmology \& Visual Science 32(13):3145-3166.

Caprioli J, Sears M. 1984. Combined effect of forskolin and acetazolamide on intraocular pressure and aqueous flow in rabbit eyes. Experimental Eye Research 39(1):47-50.

Carre DA, Tang CS, Krupin T, Civan MM. 1992. Effect of bicarbonate on intracellular potential of rabbit ciliary epithelium. Current Eye Research 11(7):609-624.

Chen H-B, Yamabayashi S, Ou BO, Tsukahara S. 1996. Morphological Changes in Rabbit Ciliary Epithelium and Blood-Aqueous Barriers after Intravitreal 10-5Endothelin-1. Experimental Eye Research 62(6):605-612.

Chu TC, Candia OA. 1988. Active transport of ascorbate across the isolated rabbit ciliary epithelium. Investigative Ophthalmology \& Visual Science 29(4):594-599.

Civan MM. 1998. Transport components of net secretion of the aqueous humour and their integrated regulation. The Eye's Aqueous Humor: From secretion to glaucoma. San Diego, London, Boston, New York, Sydney, Tokyo, Toronto: Academic Press. p 124.

Civan MM, Macknight AD. 2004. The ins and outs of aqueous humour secretion. Experimental Eye Research 78(3):625-631.

Coakes RL, Brubaker RF. 1978. The mechanism of timolol in lowering intraocular pressure. In the normal eye. Archives of Ophthalmology 96(11):2045-2048.

Coca-Prados M, Ghosh S, Gilula NB, Kumar NM. 1992. Expression and cellular distribution of the alpha 1 gap junction gene product in the ocular pigmented ciliary epithelium. Current Eye Research 11(2):113-122.

Cole DF. 1977. Secretion of the aqueous humour. Experimental Eye Research 25 Suppl:161176.

Cole DF, Monro PA. 1976. The use of fluorescein-labelled dextrans in investigation of aqueous humour outflow in the rabbit. Experimental Eye Research 23(6):571-585.

Cooper RL, Constable IJ, Davidson L. 1984. Catecholamines in aqueous humour of glaucoma patients. Australian Journal of Ophthalmology 12(4):345-349. 
Counillon L, Touret N, Bidet M, Peterson-Yantorno K, Coca-Prados M, Stuart-Tilley A, Wilhelm S, Alper SL, Civan MM. 2000. Na+/H+ and CI-/HCO3-antiporters of bovine pigmented ciliary epithelial cells. Pflugers Archiv - European Journal of Physiology 440(5):667-678.

Crook RB, Riese K. 1996. Beta-adrenergic stimulation of $\mathrm{Na}+, \mathrm{K}+, \mathrm{Cl}-$ cotransport in fetal nonpigmented ciliary epithelial cells. Investigative Ophthalmology \& Visual Science 37(6):1047-1057.

Cunha-Vaz J. 1979. The blood-ocular barriers. Survey of Ophthalmology 23(5):279-296.

Dailey RA, Brubaker RF, Bourne WM. 1982. The effects of timolol maleate and acetazolamide on the rate of aqueous formation in normal human subjects. American Journal of Ophthalmology 93(2):232-237.

Davson H. 1969. The intraocular fluids. Davson H, editor. London: Academic press. 67-72 p.

Davson H. 1990. Physiology of the Eye. New york, Oxford, Beijing, Frankfurt, Sao Paulo, Sydney, Tokyo, Toronto: Pergamon Press. 3-95 p.

DiMattio J, Altszuler N, Ellis S, Zadunaisky JA. 1981. Glucose transport across ocular barriers of the streptozotocin-diabetic rat. Diabetes 30(11):903-906.

Do CW, Civan MM. 2009. Species variation in biology and physiology of the ciliary epithelium: similarities and differences. Experimental Eye Research 88(4):631-640.

Do CW, To CH. 2000. Chloride secretion by bovine ciliary epithelium: a model of aqueous humor formation. Investigative Ophthalmology \& Visual Science 41(7):1853-1860.

Dollery CT, Henkind P, Orme ML. 1971. Assimilation of D and L I-C-14 glucose into the retina, brain and other tissues. Diabetes 20(8):519-521.

Duke-Elder WS. 1926. The ocular circulation: Its normal pressure relationships and their physiological significance. British Journal of Ophthalmology 10(10):513-572.

Dunn JJ, Lytle C, Crook RB. 2001. Immunolocalization of the Na-K-Cl cotransporter in bovine ciliary epithelium. Investigative Ophthalmology \& Visual Science 42(2):343353.

Edelman JL, Loo DD, Sachs G. 1995. Characterization of potassium and chloride channels in the basolateral membrane of bovine nonpigmented ciliary epithelial cells

Investigative Ophthalmology \& Visual Science 36(13):2706-2716.

Edelman JL, Sachs G, Adorante JS. 1994. Ion transport asymmetry and functional coupling in bovine pigmented and nonpigmented ciliary epithelial cells. American Journal of Physiology 266(5 Pt 1):C1210-1221.

Elena PP, Fredj-Reygrobellet D, Moulin G, Lapalus P. 1984. Pharmacological characteristics of beta-adrenergic-sensitive adenylate cyclase in non pigmented and in pigmented cells of bovine ciliary process. Current Eye Research 3(12):1383-1389.

Epstein DL, Jedziniak JA, Grant WM. 1978. Identification of heavy-molecular-weight soluble protein in aqueous humor in human phacolytic glaucoma. Investigative Ophthalmology \& Visual Science 17(5):398-402.

Forrester J, Dick A, McMenamin P, Lee W. 1996. The Eye: Basic Sciences in Practice. London, Philadelphia, Toronto, Sydney, Tokyo: WB Saunders. 13 p.

Foster PJ, Buhrmann R, Quigley HA, Johnson GJ. 2002. The definition and classification of glaucoma in prevalence surveys. British Journal of Ophthalmology 86(2):238-242.

Freddo TF. 2001. Shifting the paradigm of the blood-aqueous barrier. Experimental Eye Research 73(5):581-592. 
Freddo TF, Bartels SP, Barsotti MF, Kamm RD. 1990. The source of proteins in the aqueous humor of the normal rabbit. Investigative Ophthalmology \& Visual Science 31(1):125-137.

Gadea A, Schinelli S, Gallo V. 2008. Endothelin-1 Regulates Astrocyte Proliferation and Reactive Gliosis via a JNK/c-Jun Signaling Pathway. J Neurosci 28(10):2394-2408.

Gao Q, Li Y, Shen L, Zhang J, Zheng X, Qu R, Liu Z, Chopp M. 2008. Bone marrow stromal cells reduce ischemia-induced astrocytic activation in vitro. Neuroscience 152(3):646-655.

Ghanem AA, Arafa LF, El-Baz A. 2011. Connective tissue growth factor and tissue inhibitor of matrix metalloproteinase-2 in patients with exfoliative glaucoma. Current Eye Research 36(6):540-545.

Gharagozloo NZ, Relf SJ, Brubaker RF. 1988. Aqueous flow is reduced by the alphaadrenergic agonist, apraclonidine hydrochloride (ALO 2145). Ophthalmology 95(9):1217-1220.

Ghosh S, Freitag AC, Martin-Vasallo P, Coca-Prados M. 1990. Cellular distribution and differential gene expression of the three alpha subunit isoforms of the $\mathrm{Na}, \mathrm{K}-\mathrm{ATPase}$ in the ocular ciliary epithelium. Journal of Biological Chemistry 265(5):2935-29340.

Ghosh S, Hernando N, Martin-Alonso JM, Martin-Vasallo P, Coca-Prados M. 1991. Expression of multiple $\mathrm{Na}+, \mathrm{K}(+)$-ATPase genes reveals a gradient of isoforms along the nonpigmented ciliary epithelium: functional implications in aqueous humor secretion. Journal of Cellular Physiology 149(2):184-194.

Gilula NB, Reeves OR, Steinbach A. 1972. Metabolic coupling, ionic coupling and cell contacts. Nature 235(5336):262-265.

Gloor BP. 1987. "The Vitreous," Adler's Physiology of the Eye. Moses RA, Hart WM, editors. Saint Louis: The C. V. Mosby Co. 246-267 p.

Green K. 1984. Physiology and pharmacology of aqueous humor inflow. Survey of Ophthalmology 29(3):208-214.

Haas M. 1994. The Na-K-Cl cotransporters. American Journal of Physiology 267(4 Pt 1):C869-885.

Harris LS, Shimmyo M, Mittag TW. 1973. Cholinesterases and contractility of cat irides. Effect of echothiophate iodide. Archives of Ophthalmology 89(1):49-51.

He S, Prasanna G, Yorio T. 2007. Endothelin-1-Mediated Signaling in the Expression of Matrix Metalloproteinases and Tissue Inhibitors of Metalloproteinases in Astrocytes. Invest Ophthalmol Vis Sci 48(8):3737-3745.

He Z, Vingrys AJ, Armitage JA, Bui BV. 2011. The role of blood pressure in glaucoma. Clinical \& Experimental Optometry 94(2):133-149.

Helbig H, Korbmacher C, Kuhner D, Berweck S, Wiederholt M. 1988a. Characterization of $\mathrm{Cl}$-/HCO3- exchange in cultured bovine pigmented ciliary epithelium. [erratum appears in Exp Eye Res 1989 Feb;48(2):319]. Experimental Eye Research 47(4):515523.

Helbig H, Korbmacher C, Nawrath M, Erb C, Wiederholt M. 1989a. Sodium bicarbonate cotransport in cultured pigmented ciliary epithelial cells. Current Eye Research 8(6):595-598.

Helbig H, Korbmacher C, Stumpff F, Coca-Prados M, Wiederholt M. 1988b. Na+/H+ exchange regulates intracellular $\mathrm{pH}$ in a cell clone derived from bovine pigmented ciliary epithelium. Journal of Cellular Physiology 137(2):384-389. 
Helbig H, Korbmacher C, Wohlfarth J, Coca-Prados M, Wiederholt M. 1989b. Electrical membrane properties of a cell clone derived from human nonpigmented ciliary epithelium. Investigative Ophthalmology \& Visual Science 30(5):882-889.

Hernandez MR. 2000. The optic nerve head in glaucoma: role of astrocytes in tissue remodeling. Progress in Retinal and Eye Research 19(3):297-321.

Hernandez MR, Miao H, Lukas T. 2008. Astrocytes in glaucomatous optic neuropathy. Progress in Brain Research 173:353-373.

$\mathrm{Hu}$ RG, Lim JC, Kalloniatis M, Donaldson PJ. 2011. Cellular localization of glutamate and glutamine metabolism and transport pathways in the rat ciliary epithelium. Investigative Ophthalmology \& Visual Science 52(6):3345-3353.

Hurvitz LM, Kaufman PL, Robin AL, Weinreb RN, Crawford K, Shaw B. 1991. New developments in the drug treatment of glaucoma. Drugs 41(4):514-532.

Inada K, Baba H, Okamura R. 1984. Quantitative determination of human aqueous proteins by crossed immunoelectrophoresis. Japanese Journal of Ophthalmology 28(1):1-8.

Jacob TJ, Civan MM. 1996. Role of ion channels in aqueous humor formation. American Journal of Physiology 271(3 Pt 1):C703-720.

Jahn CE, Leiss O, von Bergmann K. 1983. Lipid composition of human aqueous humor. Ophthalmic Research 15(4):220-224.

Jiao X, Yang Z, Yang X, Chen Y, Tong Z, Zhao C, Zeng J, Chen H, Gibbs D, Sun X, Li B, Wakins WS, Meyer C, Wang X, Kasuga D, Bedell M, Pearson E, Weinreb RN, Leske MC, Hennis A, DeWan A, Nemesure B, Jorde LB, Hoh J, Hejtmancik JF, Zhang K. 2009. Common variants on chromosome 2 and risk of primary open-angle glaucoma in the Afro-Caribbean population of Barbados. Proceedings of the National Academy of Sciences of the United States of America 106(40):17105-17110.

Johnson DH. 2005. Trabecular meshwork and uveoscleral outflow models. Journal of Glaucoma 14(4):308-310.

Johnson EC, Morrison JC, Farrell S, Deppmeier L, Moore CG, McGinty MR. 1996. The Effect of Chronically Elevated Intraocular Pressure on the Rat Optic Nerve Head Extracellular Matrix. Experimental Eye Research 62(6):663-674.

Karlsson C, Maepea O, Alm A. 1984. Choline transport through the blood-retinal and the blood-brain barrier in vivo. Acta Ophthalmologica 62(5):763-766.

Katz IM, Hubbard WA, Getson AJ, Gould AL. 1976. Intraocular pressure decrease in normal volunteers following timolol ophthalmic solution. Investigative Ophthalmology 15(6):489-492.

Kodama T, Reddy VN, Macri FJ. 1985. Pharmacological study on the effects of some ocular hypotensive drugs on aqueous humor formation in the arterially perfused enucleated rabbit eye. Ophthalmic Research 17(2):120-124.

Kondo RP, Wang S-Y, John SA, Weiss JN, Goldhaber JI. 2000. Metabolic Inhibition Activates a Non-selective Current Through Connexin Hemichannels in Isolated Ventricular Myocytes. Journal of Molecular and Cellular Cardiology 32(10):1859-1872.

Kong C-W, Li K-K, To C-H. 2006. Chloride secretion by porcine ciliary epithelium: New insight into species similarities and differences in aqueous humor formation. Investigative Ophthalmology \& Visual Science 47(12):5428-5436.

Koskela T, Brubaker RF. 1991. The nocturnal suppression of aqueous humor flow in humans is not blocked by bright light. Investigative Ophthalmology \& Visual Science 32(9):2504-2506. 
Laird MD, Vender JR, Dhandapani KM. 2008. Opposing roles for reactive astrocytes following traumatic brain injury. NeuroSignals 16(2-3):154-164.

Lam KW, Lee PF. 1975. Analysis of ascorbate concentration in the aqueous humor by highpressure liquid chromatography. Investigative Ophthalmology 14(12):947-950.

Larsson LI, Alm A. 1998. Aqueous humor flow in human eyes treated with dorzolamide and different doses of acetazolamide. Archives of Ophthalmology 116(1):19-24.

Lee AJ, Goldberg I. 2011. Emerging drugs for ocular hypertension. Expert Opinion on Emerging Drugs 16(1):137-161.

Lei Y, Overby DR, Boussommier-Calleja A, Stamer WD, Ethier CR. 2011. Outflow physiology of the mouse eye: pressure dependence and washout. Investigative Ophthalmology \& Visual Science 52(3):1865-1871.

Leone G, Consumi M, Aggravi M, Donati A, Lamponi S, Magnani A. 2010. PVA/STMP based hydrogels as potential substitutes of human vitreous. Journal of Materials Science: Materials in Medicine 21(8):2491-2500.

Leske MC, Heijl A, Hussein M, Bengtsson B, Hyman L, Komaroff E, Early Manifest Glaucoma Trial G. 2003. Factors for glaucoma progression and the effect of treatment: the early manifest glaucoma trial. Archives of Ophthalmology 121(1):4856.

Lim JW, Kim MU, Shin M-C. 2010. Aqueous humor and plasma levels of vascular endothelial growth factor and interleukin-8 in patients with central serous chorioretinopathy. Retina 30(9):1465-1471.

Liu H, Fan S, Gulati V, Camras LJ, Zhan G, Ghate D, Camras CB, Toris CB. 2011. Aqueous humor dynamics during the day and night in healthy mature volunteers. Archives of Ophthalmology 129(3):269-275.

Maren TH. 1976. The rates of movement of $\mathrm{Na}+, \mathrm{Cl}-$, and HCO-3 from plasma to posterior chamber: effect of acetazolamide and relation to the treatment of glaucoma. Investigative Ophthalmology 15(5):356-364.

Maren TH. 2000. Carbonic anhydrase inhibition in ophthalmology: aqueous humor secretion and the development of sulfonamide inhibitors. EXS(90):425-435.

Maren TH, Conroy CW. 1993. A new class of carbonic anhydrase inhibitor. Journal of Biological Chemistry 268(35):26233-26239.

Maus TL, Larsson LI, McLaren JW, Brubaker RF. 1997. Comparison of dorzolamide and acetazolamide as suppressors of aqueous humor flow in humans. Archives of Ophthalmology 115(1):45-49.

McCannel CA, Heinrich SR, Brubaker RF. 1992. Acetazolamide but not timolol lowers aqueous humor flow in sleeping humans. Graefes Archive for Clinical \& Experimental Ophthalmology 230(6):518-520.

McLaughlin CW, Zellhuber-McMillan S, Macknight ADC, Civan MM. 2007. Electron microprobe analysis of rabbit ciliary epithelium indicates enhanced secretion posteriorly and enhanced absorption anteriorly. Am J Physiol Cell Physiol 293(5):C1455-1466.

Miller S, Steinberg RH. 1976. Transport of taurine, L-methionine and 3-o-methyl-D-glucose across frog retinal pigment epithelium. Experimental Eye Research 23(2):177-189.

Mori N, Yamada E, Sears ML. 1991. Immunocytochemical localization of Na/K-ATPase in the isolated ciliary epithelial bilayer of the rabbit. Archives of Histology \& Cytology 54(3):259-265. 
Moses RA. 1990. Intraocular pressure. Adler's Physiology of the Eye. p 223-245.

Nathanson JA. 1980. Adrenergic regulation of intraocular pressure: identification of beta 2adrenergic-stimulated adenylate cyclase in ciliary process epithelium. Proceedings of the National Academy of Sciences of the United States of America 77(12):74207424 .

Nilsson SF. 1997. The uveoscleral outflow routes. Eye 11(Pt 2):149-154.

Novack GD, Leopold IH. 1988. The blood-aqueous and blood-brain barriers to permeability. American Journal of Ophthalmology 105(4):412-416.

Oh J, Krupin T, Tang LQ, Sveen J, Lahlum RA. 1994. Dye coupling of rabbit ciliary epithelial cells in vitro. Investigative Ophthalmology \& Visual Science 35(5):2509-2514.

Pappas GD, Smelter GK. 1958. Studies on the ciliary epithelium and zonule. Am J Ophthalmology 46:299-318.

Pappas GD, Smelter GK. 1961. The fine structure of the ciliary epithelium in relation to aqueous humor secretion. In the Structure of the Eye. Smelter GK, editor. New York: Academic Press. 453-467 p.

Pease ME, McKinnon SJ, Quigley HA, Kerrigan-Baumrind LA, Zack DJ. 2000. Obstructed axonal transport of BDNF and its receptor TrkB in experimental glaucoma. Investigative Ophthalmology \& Visual Science 41(3):764-774.

Peyman GA, Apple D. 1972. Peroxidase diffusion processes in the optic nerve. Archives of Ophthalmology 88(6):650-654.

Peyman GA, Bok D. 1972. Peroxidase diffusion in the normal and laser-coagulated primate retina. Investigative Ophthalmology 11(1):35-45.

Polansky JR, Zlock D, Brasier A, Bloom E. 1985. Adrenergic and cholinergic receptors in isolated non-pigmented ciliary epithelial cells. Current Eye Research 4(4):517-522.

Prince JH, Diesem CD, Eglitis I, Ruskell GL. 1960. Cattle. In "Anatomy and Hiostology of the Eye and Orbit in Domestic Animals." Illianois: Thomas Springfield. 171-175 p.

Quigley HA. 2011. Glaucoma. Lancet 377(9774):1367-1377.

Quigley HA, Broman AT. 2006. The number of people with glaucoma worldwide in 2010 and 2020. British Journal of Ophthalmology 90(3):262-267.

Quill B, Docherty NG, Clark AF, O'Brien CJ. 2011. The effect of graded cyclic stretching on extracellular matrix-related gene expression profiles in cultured primary human lamina cribrosa cells. Investigative Ophthalmology \& Visual Science 52(3):19081915.

Rahman MQ, Ramaesh K, Montgomery DMI. 2010. Brimonidine for glaucoma. Expert Opinion on Drug Safety 9(3):483-491.

Rao KN, Nagireddy S, Chakrabarti S. 2011. Complex genetic mechanisms in glaucoma: an overview. Indian Journal of Ophthalmology 59 Suppl:S31-42.

Raviola G. 1977. The structural basis of the blood-ocular barriers. Experimental Eye Research 25 Suppl:27-63.

Raviola G, Raviola E. 1978. Intercellular junctions in the ciliary epithelium. Investigative Ophthalmology \& Visual Science 17(10):958-981.

Realini T. 2011. A history of glaucoma pharmacology. Optometry \& Vision Science 88(1):3638.

Reddy VN. 1979. Dynamics of transport systems in the eye. Friedenwald Lecture. Investigative Ophthalmology \& Visual Science 18(10):1000-1018.

Redslob E. 1932. Le Corps Vitre. Paris: Masson \& Cie. pp218-306 p. 
Reiss GR, Lee DA, Topper JE, Brubaker RF. 1984. Aqueous humor flow during sleep. Investigative Ophthalmology \& Visual Science 25(6):776-778.

Riley MV. 1983. The Chemistry of aqueous humor. In: Anderson RE, editor. Biochemistry of the Eye. Sanfrancisco: American Academy of Ophthalmology. p 79-95.

Riley MV, Kishida K. 1986. ATPases of ciliary epithelium: cellular and subcellular distribution and probable role in secretion of aqueous humor. Experimental Eye Research 42(6):559-568.

Robin AL. 1988. Short-term effects of unilateral 1\% apraclonidine therapy. Archives of Ophthalmology 106(7):912-915.

Sacca SC, Izzotti A, Rossi P, Traverso C. 2007. Glaucomatous outflow pathway and oxidative stress. Experimental Eye Research 84(3):389-399.

Saez JC, Berthound VM, Moreno AP, Spray DC. 1993. Gap junctions: mulplicity of controls in differentiated and undiffrentiated cells and possible functional implications. . In: Shenolikar S, Nairn AC, editors. Advances in Cyclic Nucleotide and Phosphoprotein Res Vol 27. New York: Raven Press. p 163-198.

Scemes E, Suadicani SO, Dahl G, Spray DC. 2007. Connexin and pannexin mediated cell-cell communication. Neuron GLIA Biology 3(3):199-208.

Shahidullah M, Tamiya S, Delamere NA. 2007. Primary culture of porcine nonpigmented ciliary epithelium. Current Eye Research 32(6):511-522.

Shahidullah M, To C-H, Pelis RM, Delamere NA. 2009. Studies on bicarbonate transporters and carbonic anhydrase in porcine nonpigmented ciliary epithelium. Investigative Ophthalmology \& Visual Science 50(4):1791-1800.

Shahidullah M, Wilson WS, Millar C. 1995. Effects of timolol, terbutaline and forskolin on IOP, aqueous humour formation and ciliary cyclic AMP levels in the bovine eye. Current Eye Research 14(7):519-528.

Shahidullah M, Wilson WS, Yap M, To CH. 2003. Effects of ion transport and channelblocking drugs on aqueous humor formation in isolated bovine eye. Investigative Ophthalmology \& Visual Science 44(3):1185-1191.

Sihota R. 2011. Classification of primary angle closure disease. Current Opinion in Ophthalmology 22(2):87-95.

Smelser GK, Ishikawa T, F. PY. 1965. Electron microscope studies on intra-retinal spaces: diffusion of particle material. . In: Rohen JW, editor. Structure of the Eye, II Symp. p 109-120.

Smith RS, Rudt LA. 1975. Ocular vascular and epithelial barriers to microperoxidase. Investigative Ophthalmology 14(7):556-560.

Spector A, Garner WH. 1981. Hydrogen peroxide and human cataract. Experimental Eye Research 33(6):673-681.

Sullmann H. 1951. Chemis des Auges. Tabul Biol 22:79.

Terelak-Borys B, Liberek I. 2007a. Neuro-hormonal regulation of aqueous humor dynamics as the basis of glaucoma pharmacotherapy. Part I. Aqueous humor secretion]. Klinika Oczna 109(1-3):60-63.

Terelak-Borys B, Liberek I. 2007b. Neuro-hormonal regulation of aqueous humor dynamics as the basis of glaucoma pharmacotherapy. Part II - Aqueous humor outflow. Klinika Oczna 109(1-3):64-67.

Tezel G. 2006. Oxidative stress in glaucomatous neurodegeneration: mechanisms and consequences. Progress in Retinal \& Eye Research 25(5):490-513. 
Tezel G, Wax MB. 2004. Hypoxia-inducible factor 1alpha in the glaucomatous retina and optic nerve head. Archives of Ophthalmology 122(9):1348-1356.

To CH, Kong CW, Chan CY, Shahidullah M, Do CW. 2002. The mechanism of aqueous humour formation. Clinical \& Experimental Optometry 85(6):335-349.

Topper JE, Brubaker RF. 1985. Effects of timolol, epinephrine, and acetazolamide on aqueous flow during sleep. Investigative Ophthalmology \& Visual Science 26(10):1315-1319.

Toris CB, Gabelt BAT, Kaufman PL. 2008. Update on the mechanism of action of topical prostaglandins for intraocular pressure reduction. Survey of Ophthalmology 53 Suppl1:S107-120.

Toris CB, Zhan GL, Yablonski ME, Camras CB. 2004. Effects on aqueous flow of dorzolamide combined with either timolol or acetazolamide. Journal of Glaucoma 13(3):210-215.

Tripathi RC, Millard CB, Tripathi BJ. 1989. Protein composition of human aqueous humor: SDS-PAGE analysis of surgical and post-mortem samples. Experimental Eye Research 48(1):117-130.

Trope GE, Rumley AG. 1985. Catecholamines in human aqueous humor. Investigative Ophthalmology \& Visual Science 26(3):399-401.

Tschumper RC, Johnson DH. 1990. Trabecular meshwork cellularity. Differences between fellow eyes. Investigative Ophthalmology \& Visual Science 31(7):1327-1331.

Usukura J, Fain GL, Bok D. 1988. [3H] ouabain localization of Na-K ATPase in the epithelium of rabbit ciliary body pars plicata. Investigative Ophthalmology \& Visual Science 29(4):606-614.

Vanlandingham BD, Maus TL, Brubaker RF. 1998. The effect of dorzolamide on aqueous humor dynamics in normal human subjects during sleep. Ophthalmology 105(8):1537-1540.

Vegge T. 1971. An electron microscopic study of the permeability of iris capillaries to horseradish peroxidase in the vervet monkey (Cercopithecus aethiops). Ptschrift Fur Zellforschung Und Mikroskopische Anatomielexus 121(1):74-81.

Vorwerk CK, Naskar R, Dreyer EB. 1999. The excitotoxicity theory of glaucoma. Klinische Monatsblatter fur Augenheilkunde 214(1):2-11.

Wang RF, Serle JB, Podos SM, Sugrue MF. 1991. MK-507 (L-671,152), a topically active carbonic anhydrase inhibitor, reduces aqueous humor production in monkeys. Archives of Ophthalmology 109(9):1297-1299.

Wang Z, Do CW, Valiunas V, Leung CT, Cheng AKW, Clark AF, Wax MB, Chatterton JE, Civan MM. 2010. Regulation of gap junction coupling in bovine ciliary epithelium. American Journal of Physiology - Cell Physiology 298(4):C798-806.

Watanabe K, Chiou GC. 1983. Action mechanism of timolol to lower the intraocular pressure in rabbits. Ophthalmic Research 15(3):160-167.

Wax MB, Molinoff PB. 1987. Distribution and properties of beta-adrenergic receptors in human iris-ciliary body. Investigative Ophthalmology \& Visual Science 28(3):420430 .

Wax MB, Tezel G. 2009. Immunoregulation of retinal ganglion cell fate in glaucoma. Experimental Eye Research 88(4):825-830.

Wheeler L, WoldeMussie E, Lai R. 2003. Role of alpha-2 agonists in neuroprotection. Survey of Ophthalmology 48(Suppl 1):S47-S51. 
Wiederholt M, Zadunaisky JA. 1986. Membrane potentials and intracellular chloride activity in the ciliary body of the shark. Pflugers Archiv - European Journal of Physiology 407(Suppl 2):S112-115.

Wood JP, Schmidt KG, Melena J, Chidlow G, Allmeier H, Osborne NN. 2003. The betaadrenoceptor antagonists metipranolol and timolol are retinal neuroprotectants: comparison with betaxolol. Experimental Eye Research 76(4):505-516.

Yanagi M, Kawasaki R, Wang JJ, Wong TY, Crowston J, Kiuchi Y. 2011. Vascular risk factors in glaucoma: a review. Clinical \& Experimental Ophthalmology 39(3):252-258.

Zimmerman TJ, Garg LC, Vogh BP, Maren TH. 1976. The effect of acetazolamide on the movements of anions into the posterior chamber of the dog eye. Journal of Pharmacology \& Experimental Therapeutics 196(2):510-516. 


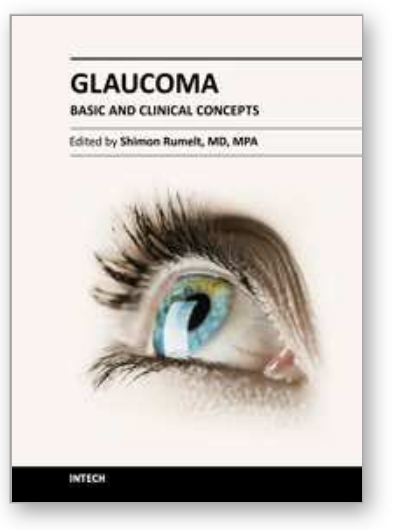

\author{
Glaucoma - Basic and Clinical Concepts \\ Edited by Dr Shimon Rumelt
}

ISBN 978-953-307-591-4

Hard cover, 590 pages

Publisher InTech

Published online 11, November, 2011

Published in print edition November, 2011

This book addresses the basic and clinical science of glaucomas, a group of diseases that affect the optic nerve and visual fields and is usually accompanied by increased intraocular pressure. The book incorporates the latest development as well as future perspectives in glaucoma, since it has expedited publication. It is aimed for specialists in glaucoma, researchers, general ophthalmologists and trainees to increase knowledge and encourage further progress in understanding and managing these complicated diseases.

\title{
How to reference
}

In order to correctly reference this scholarly work, feel free to copy and paste the following:

Mohammad Shahidullah, Waleed Hassan Al-Malki and Nicholas A. Delamere (2011). Mechanism of Aqueous Humor Secretion, Its Regulation and Relevance to Glaucoma, Glaucoma - Basic and Clinical Concepts, Dr Shimon Rumelt (Ed.), ISBN: 978-953-307-591-4, InTech, Available from:

http://www.intechopen.com/books/glaucoma-basic-and-clinical-concepts/mechanism-of-aqueous-humorsecretion-its-regulation-and-relevance-to-glaucoma

\section{INTECH}

open science | open minds

\section{InTech Europe}

University Campus STeP Ri

Slavka Krautzeka 83/A

51000 Rijeka, Croatia

Phone: +385 (51) 770447

Fax: +385 (51) 686166

www.intechopen.com

\section{InTech China}

Unit 405, Office Block, Hotel Equatorial Shanghai

No.65, Yan An Road (West), Shanghai, 200040, China

中国上海市延安西路65号上海国际贵都大饭店办公楼 405 单元

Phone: +86-21-62489820

Fax: $+86-21-62489821$ 
(C) 2011 The Author(s). Licensee IntechOpen. This is an open access article distributed under the terms of the Creative Commons Attribution 3.0 License, which permits unrestricted use, distribution, and reproduction in any medium, provided the original work is properly cited. 